\title{
DOENÇAS DA CAVIDADE NASAL DE RUMINANTES
}

\author{
RUMINANT’S NASAL CAVITY DISEASES
}

\author{
Gildeni Maria Nascimento de Aguiar ${ }^{1}{ }^{\circledR}$, Lisanka Angelo Maia ${ }^{2}{ }^{(}$, Isabela Calixto Matias $^{3}{ }^{(}$, \\ Antônio Flávio Medeiros Dantas ${ }^{4}{ }^{\circledR}$, Sara Vilar Dantas Simões ${ }^{50}$
}

Universidade Federal de Alagoas (UFAL), Campus CECA, Unidade de Ensino Viçosa, Curso de Medicina Veterinária, Viçosa, Alagoas, Brasil.

Instituto Federal de Educação Ciência e Tecnologia (IFPB), Campus Sousa, Curso de Medicina Veterinária, Sousa, Paraíba, Brasil.

Universidade Federal de Campina Grande (UFCG), Campus Patos, Programa de Pós-graduação em Ciência e Saúde Animal, Patos, Paraíba, Brasil.

Universidade Federal de Campina Grande (UFCG), Campus Patos, Unidade Acadêmica de Medicina Veterinária, Patos, Paraíba, Brasil.

Universidade Federal da Paraíba (UFPB), Centro de Ciências Agrárias, Curso de Medicina Veterinária, Areia, Paraíba, Brasil.

Autor para correspondência: gildeni.aguiar@vicosa.ufal.br

Revista Brasileira de Buiatria Clínica Médica, Volume 1, Número 6, 2021

ISSN 2763-955X

DOI:10.4322/2763-955X.2021.006

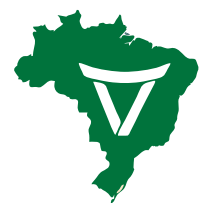

Associação Brasileira de Buiatria

\section{RESUMO}

As afecções da cavidade nasal possuem etiologia diversificada, incluindo agentes infecciosos, parasitos, reações alérgicas e neoplasias. A exposição dos animais aos agentes e o desequilíbrio dos mecanismos de defesa, inerentes à cavidade nasal, são os principais fatores relacionados à ocorrência dessas. A maioria das afecções apresentam características clínicas e epidemiológicas semelhantes, necessitando de adequado exame clínico e uso de técnicas diagnósticas auxiliares que permitam a determinação dos diagnósticos etiológicos. Objetivando colaborar com informações para auxiliar na identificação e controle dessas enfermidades apresenta-se nessa revisão os principais agentes etiológicos, aspectos semiológicos, sinais clínicos, caracterização anatomopatológica das lesões e considerações sobre métodos auxiliares de diagnóstico das afecções mais frequentes. Estas informações poderão auxiliar os médicos veterinários a adotarem procedimentos terapêuticos e medidas profiláticas que possam vir a reduzir os prognósticos desfavoráveis e alta letalidade que acompanham essas enfermidades, principalmente quando são diagnosticadas tardiamente.

Palavras-chave: diagnóstico, neoplasias, rinites, semiologia, trato respiratório superior.

\section{ABSTRACT}

Diseases of the nasal cavity have a diverse etiology, including infectious agents, parasites, allergic reactions, and neoplasms. The exposure of animals to these agents and the imbalance of defense mechanisms of the nasal cavity are the main factors related to their occurrence. Most conditions present similar clinical and epidemiological characteristics, requiring adequate clinical examination and the use of ancillary diagnostic techniques that allow to precisely determine the etiological diagnosis. To provide helpful information to assist in the identification and control of these diseases, this review presents the main etiological agents, semiological aspects, clinical signs, anatomopathological characterization of the lesions and additional considerations on diagnostic methods for the most frequent disorders. This review may help veterinarians to adopt proper therapeutic procedures and prophylactic measures that may reduce unfavorable prognosis and the high lethality rate that commonly follows these diseases, especially when there is a late diagnosis.

Keywords: diagnosis, neoplasms, rhinitis, semiology, upper respiratory tract. 


\section{INTRODUÇÃO}

A cavidade nasal, além das funções de filtração, aquecimento e umidificação do ar inspirado, desempenha um importante papel de defesa do trato respiratório. O epitélio ciliado, a presença de células caliciformes produtoras de muco e sua anatomia com meatos estreitos e arranjo espiralado, que provoca turbulência no ar inspirado, permitem que partículas aéreas veiculando agentes invasores fiquem aderidas à mucosa e posteriormente sejam expelidas. Um outro componente importante de defesa é a microbiota saprófita, que atua por competição, impedindo a colonização do trato respiratório por organismos de potencial patogênico, alguns já presentes na cavidade. Esses fatores de proteção, além de secreção de muco, batimentos ciliares e imunoglobulinas, complementam os mecanismos de defesa da cavidade. Contudo, em condições de desequilibrio desses mecanismos há favorecimento da colonização e desenvolvimento de organismos patogênicos, resultando em inflamação ${ }^{1}$.

Apesar de menos prevalentes que as doenças pulmonares, as enfermidades da cavidade nasal e seios paranasais se destacam pelo extremo desconforto que ocasionam aos animais dificuldade no diagnóstico e tratamento e pela maioria possuir alta letalidade.

Entre os agentes etiológicos responsáveis por afecções da cavidade nasal de ruminantes destacam-se fungos como: Conidiobolus sp..$^{2-4}$, Cryptococcus sp. ${ }^{5,6}$, Aspergillus sp. ${ }^{7}$, o oomiceto Pytbium insidiosum ${ }^{8}$ e, esporadicamente, algas como Prototheca wickerbamii ${ }^{9}$, causando rinites granulomatosas. Outros agentes fúngicos como Pseudallescheria boydii ${ }^{10}$, Drechslera balodes ${ }^{11} \mathrm{e}$ Coccidioides immitis foram associados ao granuloma nasal bovino, enfermidade que pode ter também origem alérgica, bacteriana ${ }^{12}$ ou o envolvimento do $R b i-$ nosporidium seeberi, um protista pertencente a nova classe Mesomycetozoa ${ }^{13}$, anteriormente classificado como fungo ${ }^{14}$. Agentes bacterianos e virais, como Acti- nomyces bovis, Actinobacillus lignieresii, Herpesvírus Bovino tipo I, Vírus do Tumor Etmoidal Enzoótico dos Ovinos, e parasitários, como as larvas de dípteros Oestrus ovis ${ }^{15}$, podem comprometer a cavidade nasal. Neoplasias, embora pouco frequentes, também ocorrem na cavidade nasal de ruminantes, principalmente nos bovinos ${ }^{16}$.

Embora as afecções da cavidade nasal sejam ocasionadas por um grupo heterogêneo de agentes etiológicos, apresentam sintomatologia semelhante $o$ que dificulta o diagnóstico. Além disso, observa-se que algumas vezes o exame da cavidade nasal e demais vias aéreas superiores é negligenciado, e as enfermidades que têm origem nessas estruturas são equivocadamente interpretadas como sendo das vias aéreas inferiores. Dessa forma, o exame clínico, o conhecimento da epidemiologia, a colheita e remessa de material para exames complementares são fundamentais para a elucidação do diagnóstico. Objetivando colaborar com o diagnóstico das afecções da cavidade nasal, apresenta-se nessa revisão as principais características epidemiológicas, clínicas e patológicas dessas enfermidades.

\section{ASPECTOS EPIDEMIOLÓGICOS}

Algumas doenças da cavidade nasal apresentam aspectos epidemiológicos semelhantes, portanto optou-se por apresentar conjuntamente nesta seção os associados às enfermidades causadas por fungos (conidiobolomicose, aspergilose, criptococose), algas (prototecose), oomicetos (pitiose), parasitos (oestrose) e granuloma nasal. Posteriormente, as características clínicas e patológicas dessas enfermidades serão abordadas individualmente.

As enfermidades causadas por fungos, oomicetos e algas são adquiridas principalmente através do contato do animal com agentes presentes no ambiente, especialmente no solo, não sendo frequente a transmissão horizontal entre os animais ${ }^{17}$. A manutenção e o 
desenvolvimento dos agentes no ambiente sofrem influência de fatores como umidade e altas temperaturas. Essas condições são comumente relatadas nos casos de conidiobolomicose, aspergilose, pitiose e prototecose nasal. A temperatura e umidade também influenciam no desenvolvimento de larvas da mosca Oestrus ovis, ainda que os casos possam ser observados em qualquer época do ano. As temperaturas mais amenas contribuem para uma maior ocorrência ${ }^{18,19}$. O granuloma nasal de origem alérgica aparece de forma sazonal. No Rio Grande do Sul o verão costuma ser o período no qual os sinais clínicos são exacerbados e vão gradualmente desaparecendo até a remissão no inverno ${ }^{12}$.

Na região Nordeste e nos estados do Rio Grande do $\mathrm{Sul}^{20}$, Mato Grosso ${ }^{21}$, Goiás ${ }^{22}$ e Tocantins ${ }^{23}$ um maior número de casos de conidiobolomicose e pitiose nasal tendem a acontecer nos meses de maior precipitação pluviométrica, de janeiro a julho. Um outro aspecto epidemiológico importante da conidiobolomicose e pitiose nasal no Nordeste é o pastejo dos animais em margens de açudes, principalmente porque essas áreas se mantêm úmidas e com a presença de forragem, mesmo em época de estiagem (Figura 1A).Destaca-se também que é comum existirem nestes reservatórios plantas aquáticas que entram em decomposição à medida que o volume de água dos açudes reduzem (Figura 1B). Essa matéria vegetal em decomposição, associada a umidade das margens e as altas temperaturas características da região, proporcionam um microambiente que favorece a proliferação do Conidiobolus sp. e, consequentemente, a inalação do agente pelos animais. Essa condição justifica a ocorrência de casos das doenças também no período seco, porém em uma frequência menor que no período chuvoso. Em outras regiões, o pastejo em locais úmidos como resteva de $\operatorname{arroz}^{22}$, margens de rios ${ }^{24}$ ou lagos ${ }^{25}$ também devem ser considerados na epidemiologia dessas doenças por favorecer o desenvolvimento do agente.

P. insidiosum está presente em açudes e outros ambientes úmidos, pois o mesmo realiza seu ciclo de vida em ambientes aquáticos. A infecção ocorre, possivelmente, durante a alimentação ou consumo de água (Figura 1C), em açudes contendo os zoósporos móveis, forma infectante do agente, que tem quimiotaxia por tecidos, penetrando na pele dos animais causando a enfermidade ${ }^{26}$.

As enfermidades da cavidade nasal são mais frequentes em ovinos, mesmo quando se tem rebanhos mistos de pequenos ruminantes ${ }^{2}$. Diversos registros sobre a ocorrência de conidiobolomicose são identificados em ovinos na literatura, sendo apenas um surto registrado em caprinos ${ }^{27}$. Possivelmente a capacidade dos ovinos de pastejar muito próximo ao solo, que difere do ramoneio dos caprinos, favorece a inalação dos esporos de Conidiobolus sp $\mathrm{sp}^{2}$. Casos de oestrose também são mais prevalentes em ovinos. Um estudo sorológico mostrou a prevalência maior de anticorpos do Oestrus ovis em ovinos, justificando os seus achados ao comportamento dos caprinos, que evitam a larviposição das moscas em suas narinas ${ }^{28}$. Em nove surtos de oestrose estudados na Bahia, oito acometeram ovinos e apenas um surto foi registrado em caprinos ${ }^{15}$. Embora aparentemente os caprinos sejam menos susceptíveis às infecções da cavidade nasal, a prototecose nasal foi registrada apenas em caprinos ${ }^{9,29}$.

Animais de diferentes raças são indistintamente acometidos pelas afecções da cavidade nasal, entretanto são frequentes os relatos de conidiobolomicose e pitiose nasal ${ }^{30}$ em ovinos Santa Inês. Tal fato pode estar associado a essa raça existir em números significantes no plantel nacional, aumentando as chances dos animais serem acometidos. Casos de conidiobolomicose no Brasil também foram descritos em ovinos das raças Morada Nova ${ }^{2}$, Texel ${ }^{20}$ e Merino. Um estudo comparando a susceptibilidade de ovinos Santa Inês e Ile de France à infecção pelo Oestrus ovis também demonstrou não existir diferença entre as raças ${ }^{31}$, e surtos da miíase nasal foram relatados envolvendo ovinos Santa Inês $^{32}$, Morada Nova e Dorper ${ }^{15}$. Criptococose nasal acometeu ovinos da raça Santa Inês ${ }^{6,33}$ e Merino ${ }^{5}$.Já no 




Figura 1. Ambiente observado em propriedades que apresentaram casos de conidiobolomicose e pitiose nasal. (A) Ovinos pastejando às margens de açude, em propriedade no município de Camalaú, Paraíba, com casos de conidiobolomicose, (B) matéria vegetal em decomposição nas margens de açude de propriedade com surto de conidiobolomicose e (C) ovinos dentro de açude e consumindo água em suas margens em propriedade no município de Jucurutu, Rio Grande do Norte, com casos de pitiose nasal.

granuloma nasal de origem alérgica há uma maior predisposição de bovinos da raça Jersey, Holandesa e Guernsey $^{34,35}$. A Jersey também é a mais predisposta ao granuloma nasal quando o agente etiológico é um fungo ${ }^{11}$.

Animais de diferentes faixas etárias são susceptíveis às enfermidades. Casos de conidiobolomicose foram identificados em animais jovens, com seis ${ }^{21} \mathrm{e}$ nove $^{36}$ meses de vida, e adultos ${ }^{20,37,38}$. Criptococose, aspergilose e prototecose nasal foram identificados apenas em animais adultos ${ }^{6,7,933}$, no entanto não é possível afirmar que existe maior predisposição nessa faixa etária, devido ao pequeno número de casos registrados.

A taxa de morbidade das enfermidades é muito variável e pode, além de fatores inerentes ao animal, estar relacionada a diferenças na exposição ao agente e a concentração do patógeno no ambiente. Há registros de taxas entre $0,66 \%$ e $73,3 \%{ }^{39}$ para conidiobolomicose, $0,89 \%(1 / 112)^{40}$ a $7,27 \%(4 / 55)^{22}$ para pitiose nasal, $0,2 \%(1 / 500)^{33}$ para criptococose nasal e $2,5 \%(1 / 40)^{29}$ na prototecose. No estado da Bahia, em oito surtos de oestrose em ovinos a morbidade variou de $0,5 \%$ a $11,4 \%$ e em um surto em caprinos chegou a $5 \%{ }^{15}$. Em uma propriedade no Mato Grosso a doença acometeu $100 \%$ do rebanho de ovinos ${ }^{32}$.

A letalidade das rinites provocadas por fungos é alta, alcançando 100\% nos casos de conidiobolomicose, criptococose $^{6,33}$, aspergilose ${ }^{7}$, assim como nos casos de prototecose $^{9,29}$. Na pitiose nasal pode chegar a $75 \%{ }^{22} \mathrm{e}$ $100 \%{ }^{39,41}$. Nos casos de oestrose a taxa de letalidade costuma ser menor, sendo observada taxas de 2,24\% $(28 / 1250)$ a $60 \%(9 / 15)$ no Mato Grosso ${ }^{32}$, até $75 \%$ na Bahia $^{15}$, e, geralmente, a morte dos animais não está associada ao parasitismo da cavidade nasal, mas, as parasitoses gastrintestinais, devido às falhas nas vermifugações.

$\mathrm{Na}$ Tabela 1 apresentam-se fatores epidemiológicos comuns a conidiobolomicose, pitiose, aspergilose, criptococose nasal e oestrose nos pequenos ruminantes. 
Tabela 1.Principais fatores epidemiológicos envolvidos nas rinites em pequenos ruminantes.

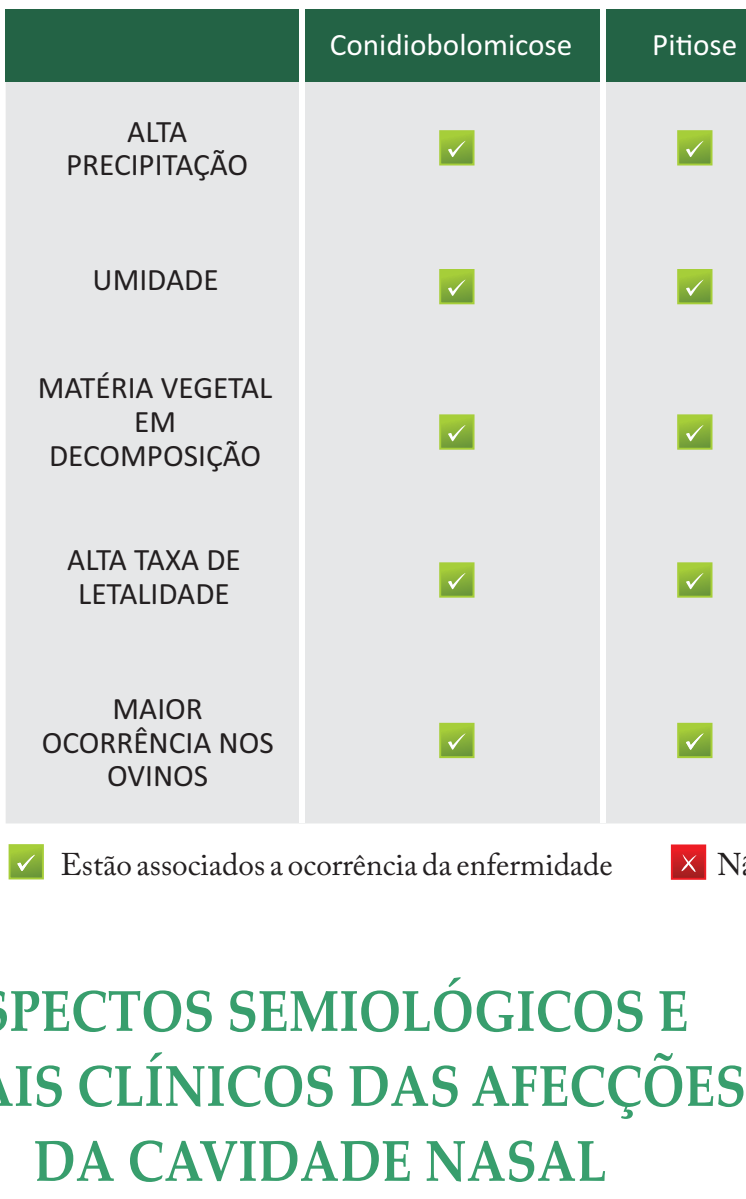

A realização de anamnese adequada, exame de todo o sistema respiratório e uma correta interpretação dos sinais identificados são imprescindíveis para o diagnóstico.

A queixa principal do proprietário geralmente envolve sinais como secreção nasal, respiração ruidosa, deformidade da cabeça e protusão do globo ocular. Registrar informações a respeito da evolução da doença é importante, pois geralmente as da cavidade nasal têm caráter crônico e progressivo. Essa característica dificulta a determinação, por parte dos produtores, do exato momento de início da doença. A obtenção de informações sobre manifestações clínicas inespecíficas apresentadas pelo animal, como afastamento do rebanho, emagrecimento e mudança de comportamento podem auxiliar a identificar o início da enfermidade.

Informações referentes à taxa de morbidade e letalidade são importantes, pois as enfermidades da cavidade nasal apresentam taxas muito características.

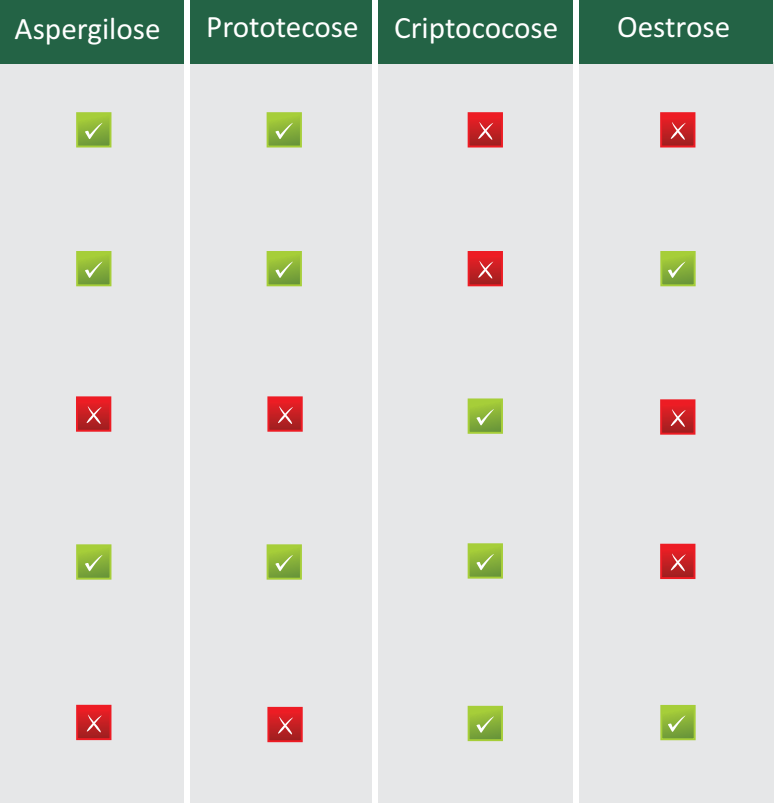

Não estão associados a ocorrência da enfermidade
Geralmente, a maioria dessas doenças acometem um único indivíduo (aspergilose ${ }^{7}$, prototecose ${ }^{9}$, neoplasi$\mathrm{as}^{42}$ ) ou tem baixa morbidade (pitiose ${ }^{43}$, rinosporidio$\left.\mathrm{se}^{14}\right)$. No entanto, podem também ser observados casos individuais em um período relativamente curto de tempo, como na conidiobolomicose $e^{39,44}$, ou ocorrência de surtos como na oestrose ${ }^{32}$. A letalidade na maioria das enfermidades é alta, exceto nos casos de oestrose e granuloma nasal.

A procedência do animal deve ser considerada, pois sabe-se que a conidiobolomicose pode se apresentar de forma endêmica no Nordeste, especialmente nos estados do Piauí, Rio Grande do Norte, Paraíba, Pernambuco e na região Centro-Oeste do Mato Grosso ${ }^{44}$.

Questionamentos a respeito de tratamentos realizados também podem ajudar no direcionamento do diagnóstico, uma vez que um número restrito de enfermidades responde de forma satisfatória aos procedimentos terapêuticos. Os animais muitas vezes já foram submetidos a tratamentos, como uso de antibióticos e anti-inflamatórios, sem resposta satisfatória.

Investigar sobre as condições ambientais às quais os animais são submetidos também é um ponto importante. No entanto, nessa etapa além de questio- 
nar o produtor rural é fundamental para o clínico ir a campo, visualizar os locais de pastejo e fontes de água disponíveis para os animais, uma vez que grande parte das afecções são adquiridas através do contato com o agente presente no ambiente. Além disso, é interessante estabelecer se há uma correlação entre o momento de ocorrência dos casos ou exacerbação de sinais clínicos e determinadas condições climáticas (estação do ano, temperatura ambiental e precipitação pluviométrica). Algumas condições climáticas podem favorecer um maior desenvolvimento de agentes infecciosos, e consequentemente, maior probabilidade de contato com eles. Para as doenças de origem alérgica certas circunstâncias favorecem o reaparecimento sazonal de casos clínicos.

O exame físico deve ser iniciado com a inspeção do animal. É importante observar a frequência respiratória, tipo de respiração e adoção de posturas associadas a disfunções respiratórias, a exemplo da postura ortopnéica (Figura 2), caracterizada por dilatação das narinas, boca entreaberta, protusão de língua, cabeça e pescoço distendidos e abdução dos membros anteriores, na tentativa de reduzir a resistência a passa- gem do fluxo de ar.

Termos como polipneia ou taquipneia devem ser utilizados para descrever elevação da frequência respiratória. No caso de aumento de frequência e amplitude do movimento respiratório o registro deve ser feito como hiperpneia. Os sinais identificados na inspeção inicial, e a sua correta interpretação, permitirá identificar se o animal apresenta uma respiração laboriosa e que pareça estar causando desconforto, que deve ser denominada como dispneia. Identificada a dispneia é preciso observar se ocorre no momento da inspiração, expiração ou igualmente durante a inspiração e a expiração (dispneia mista). A classificação da dispneia é importante na localização da doença respiratória

A dispneia inspiratória está associada a processos patológicos nas vias aéreas superiores. $\mathrm{O}$ animal realiza fortes movimentos do tórax, inspiração longa, e é possível identificar o afundamento dos espaços intercostais. Em caso de dispneia inspiratória grave o animal assume a postura ortopneica. Estenoses, corpos estranhos, inflamações ou compressões, que diminuam o lúmen das vias aéreas superiores, dificultando a entrada de ar (Figura 3), são condições que ocasionam dispneia


Figura 2. Postura ortopneica. (A) Ovino com conidiobolomicose apresentando pescoço e cabeças distendidos, além de secreção nasal serosanguinolenta na narina direita e (B) bovino com abdução dos membros torácicos, pescoço e cabeça distendidos, boca aberta e secreção nasal sanguinolenta devido fibrosarcoma (Fotos cedidas pela Clínica Médica de Grandes Animais, Hospital Veterinário Ivon Macedo Tabosa, UFCG). 
inspiratória. Nas afecções da cavidade nasal os granulomas nasais, neoplasias e as rinites granulomatosas ocasionam a proliferação de tecido na cavidade nasal, que podem causar obstrução severa à passagem de ar e dispneia inspiratória ${ }^{7,4,29}$.

Apesar da associação de dispneia inspiratória com afecções em vias aéreas superiores, na prática clínica em algumas situações é possível identificar dispneia mista em animais com enfermidades da cavidade nasal. A dispneia mista está associada a problemas como edema pulmonar, onde observa-se dificuldade de expansão pulmonar pela presença de líquido no interstício (ocasionando dispneia inspiratória) e dificuldade de saída do ar de dentro dos alvéolos devido a presença de líquido no interior dos bronquíolos (ocasionando dispneia expiratória). Em condições como broncopneumonias a dispneia mista também é observada, sendo a inspiratória devido a dificuldade de expansão pulmonar pela congestão provocada pela inflamação e a expiratória devido a presença de exsudato nos brônquios e bronquíolos. Considerando esses conceitos, as enfermidades da cavidade nasal não deveriam ocasionar um quadro de dispneia mista. Provavel- mente, a dispneia mista observada nas afecções da cavidade demonstra que os processos obstrutivos graves dificultam também a expiração, pois nos casos relatados não foram identificados comprometimentos pulmonares importantes ${ }^{6}$, que se presentes, justificariam a dispneia mista. Dessa forma, apesar da dispneia inspiratória estar mais associada a problemas em vias aéreas anteriores, é importante não excluir os problemas na cavidade nasal quando se estiver diante de uma animal apresentando dispneia mista.

Durante a inspeção deve-se observar ainda se há deformações craniofaciais, assim como presença de descargas nasais. Essas deformações ocasionam assimetria facial, que chama muito a atenção dos produtores. A assimetria pode ocorrer como consequência da resposta inflamatória associada a presença do agente infeccioso, ou neoplasia na cavidade nasal, que geralmente se estendem aos seios paranasais, região retrobulbar e podem provocar aumento de volume ipsilateral na região frontal $^{4}$ (Figura 4A) e periocular ${ }^{45}$ (Figura 4B), ocasionando em algumas circunstâncias exoftalmia. A exoftalmia pode vir acompanhada de ceratite de exposição, epífora, úlcera de córnea e perda da visão


Figura 3. Ovinos com lesões que diminuem o lúmen da narina e cavidade nasal, ocasionando redução do fluxo de ar expirado. (A) Ovino com conidiobolomicose apresentando massa avermelhada na porção rostral da cavidade nasal esquerda e (B) ovino com edema na região mucocutânea da narina esquerda (Fotos cedidas pela Clínica Médica de Grandes Animais, Hospital Veterinário Ivon Macedo Tabosa, UFCG). 

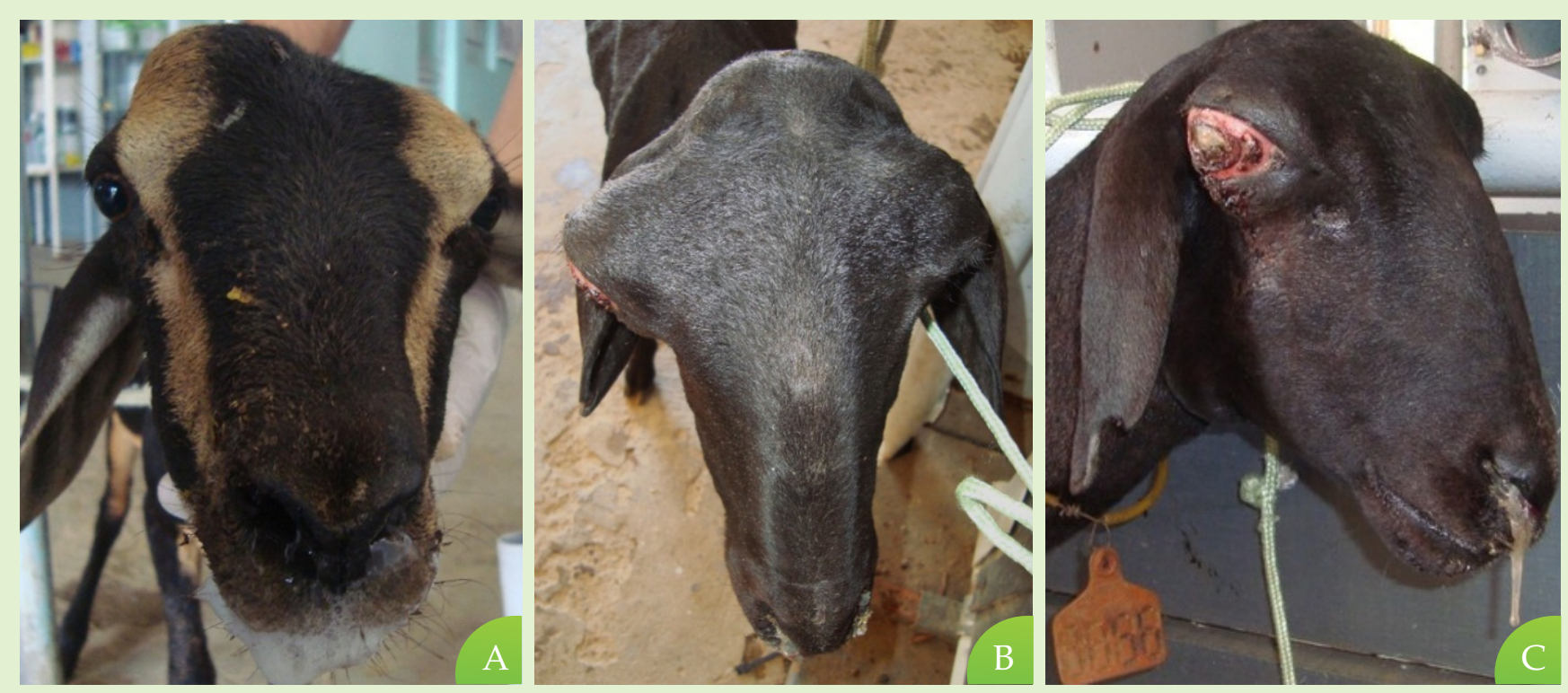

Figura 4. Deformações craniofaciais em ovinos devido a conidiobolomicose. Assimetria crânio facial com (A) aumento de volume na região frontal direita e (B) aumento da região periocular direita. (C) Exoftalmia no olho direito (Fotos cedidas pela Clínica Médica de Grandes Animais, Hospital Veterinário Ivon Macedo Tabosa, UFCG).

(Figura 4C). As deformidades são alterações comuns a diversos agentes etiológicos ${ }^{30,46}$ e na palpação geralmente tem consistência firme e não apresenta mobilidade.

A secreção nasal é um achado comum nas enfermidades ocasionadas por diversos agentes ${ }^{3,43,47}$ e deve ser investigada quanto a lateralidade (uni ou bilateral) e classificação (serosa, catarral, purulenta ou hemorrágica $)^{32,38}$. O tipo de secreção, assim como suas combinações, depende do grau de lesão da mucosa, sendo essa classificação importante para o estabelecimento de prováveis diagnósticos.

Os ruminantes possuem uma secreção nasal normal serosa, que é fluida e transparente. Quando ela se torna mais abundante, mas mantém a sua transparência, ganha significado clínico e pode ser decorrente de quadros depressivos ou inflamações iniciais do trato respiratório. À medida que essa secreção aumenta sua viscosidade e se torna mais pegajosa e esbranquiçada passa a ser denominada mucosa, que não deve ser confundida com purulenta, pois ocorre como consequência de maior produção de muco associada a processos virais ou precede a secreção identificada em infecções secundárias. Deve-se classificar a secreção nasal de purulenta quando essa torna-se densa e tem coloração amarelo-esbranquiçado ou amarelo-esverdeado, sendo visualizada quando há contaminação bacteriana e migração de células leucocitárias e restos celulares para o muco. Secreção hemorrágica, de aspecto vermelhovivo ou enegrecida, pode ser resultante de traumatismos, processos patológicos muito agressivos, lesões vasculares provocadas por corpos estranhos, ferimentos, úlceras ou pólipos.

Em relação as afecções da cavidade nasal, observa-se uma grande variação do tipo de secreção de acordo com a evolução da enfermidade (Figura 5).

$\mathrm{Na}$ inspeção da cavidade nasal é importante observar se há presença de massas pedunculadas ${ }^{6}$, nódulos, pólipos ${ }^{35}$, tumores ou corpos estranhos. O exame da porção interna da cavidade nasal, a olho nu, só permite a visualização de $1 / 4$ da fossa nasal, o que nem sempre é possível nos animais com rinites, pois muitos apresentam edema, diminuindo ainda mais o lúmen da cavidade nasal. 

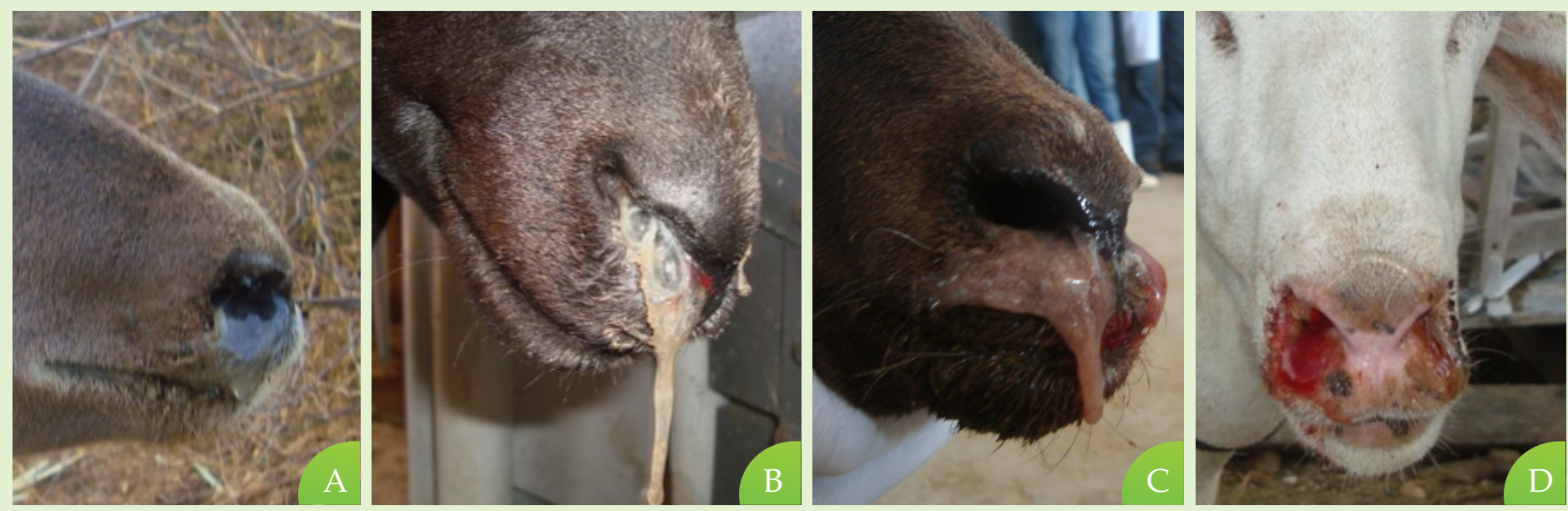

Figura 5. Variação no tipo de secreção nasal encontrada em ovinos com conidiobolomicose. (A) Secreção nasal seromucosa abundante, (B) secreção nasal mucosa, (C) secreção nasal mucopurulenta e (D) secreção nasal sanguinolenta (Fotos cedidas pela Clínica Médica de Grandes Animais, Hospital Veterinário Ivon Macedo Tabosa, UFCG).

Uma respiração ruidosa é frequentemente identificada em casos de constrição no trato respiratório superior e o som costuma ser mais alto na inspiração, principalmente os de origem nasal. A oclusão alternada de uma narina e depois da outra ajuda a determinar se a estenose é unilateral ou bilateral. Na lesão unilateral o bloqueio da narina no lado afetado deve diminuir o som, enquanto o bloqueio da outra narina deve aumentar o som, por forçar um maior fluxo de ar através da passagem nasal estenótica ${ }^{48}$.

O odor e o fluxo de ar de ambas as narinas devem ser também analisados. Nos casos de rinites em que o agente causa inflamação crônica necrosante ou necrose tumoral, um odor desagradável é perceptível no exame ${ }^{41}$. Adicionalmente, laringite necrótica, abscessos pulmonares e pneumonia por aspiração são condições que observa-se odor pútrido do ar expirado ${ }^{49}$. Em indivíduos saudáveis espera-se que o fluxo do ar expirado seja uniforme. Com o auxílio das mãos, que devem ser colocadas na frente das narinas do animal, verifica-se o fluxo alternadamente de cada narina. A sua redução permite determinar qual cavidade nasal está comprometida. O fluxo de ar desigual é visto, por exemplo, nos casos de rinite granulomatosa, neoplasias ou corpos estranhos.
A palpação de todas as partes externas do sistema respiratório deve ser realizada, mesmo em casos em que a suspeita seja de uma afecção na cavidade nasal, para assegurar se sinais clínicos como dispneia e respiração ruidosa estão associados a problemas na cavidade nasal ou são resultantes de alterações em outros locais, a exemplo de fratura de anéis traqueais ou compressões nas vias respiratórias por aumentos de volume não identificados na inspeção. A palpação dos linfonodos da cabeça deve ser realizada, pois podem estar hipertrofiados (reativos) em processos inflamatório, infeccioso ou neoplásico nas respectivas regiões de drenagem, sendo importante que se conheça as suas localizações anatômicas e áreas de drenagem, para que de fato as avaliações possam contribuir e auxiliar com o diagnóstico. Os linfonodos mandibulares ou maxilares drenam a metade ventral da cabeça, incluindo cavidade nasal, lábios, língua e glândulas salivares. Os linfonodos parotídeos drenam a parte superior da cabeça. Os linfonodos retro faríngeos drenam partes internas da cabeça, incluindo esôfago proximal, palato e faringe ${ }^{50}$. Nos casos de conidiobolomicose e pitiose chama a atenção uma marcada hipertrofia dos linfonodos da cabeça (Figura 6).

Em casos de suspeita de enfermidades na cavidade nasal, especialmente em situações onde foi identi- 
ficada redução perceptível do fluxo de ar expirado, a percussão dos seios paranasais (frontal, lacrimal e maxilar) passa a ser particularmente importante. Deve-se comparar os sons obtidos na percussão dos lados esquerdo e direito da face do animal. O preenchimento da cavidade por exsudatos ou lesões que ocupem espaço modifica o som, que passa a ser maciço, diferente do claro observado nos indivíduos saudáveis ${ }^{48,51}$. Deformações e comprometimentos ósseos podem interferir no som provocado pela percussão dos seios paranasais, dessa forma se deve associar esse exame com a inspeção e palpação do local examinado ${ }^{49}$.

Em caso de suspeita de enfermidade no trato respiratório a auscultação deve ser sempre realizada. No entanto, observa-se na prática clínica que a auscultação é frequentemente mais direcionada a região torácica, sendo a das vias aéreas anteriores negligenciada. Considerando que problemas na cavidade nasal podem cursar com estenoses, produzindo sons que se propagam pelas vias aéreas posteriores, ruídos identificados na auscultação pulmonar podem ser erroneamente interpretados como tendo origem nas vias aéreas inferiores, podendo levar a equívocos no diagnóstico. Esses equívocos ocorrem porque algumas enfermidades da cavidade nasal possuem sinais clínicos semelhantes aos identificados nos problemas pulmonares, como dispneia e secreção nasal. Caso não seja feita a auscultação das vias aéreas anteriores, os ruídos ouvidos na região torácica podem ser atribuídos a problemas pulmonares e a enfermidade da cavidade nasal não ser identificada. Deve-se atentar que a origem do som é o local onde é possível ouvi-lo com maior intensidade.

Alguns exames complementares podem auxiliar no diagnóstico das enfermidades da cavidade nasal. O exame radiográfico do trato respiratório superior é considerado de primeira escolha na avaliação das áreas e estruturas inacessíveis durante o exame físico ${ }^{52}$. É indicado principalmente nos casos em que a obstrução do fluxo de ar foi identificada, que pode ser decorrente de tumores e processos inflamatórios crônicos na cavidade. Os exames radiográficos permitem a observação de perdas e deformações ósseas, além de dar informações a respeito da extensão das massas que obstruem a cavidade nasal, principalmente em pequenos ruminantes.

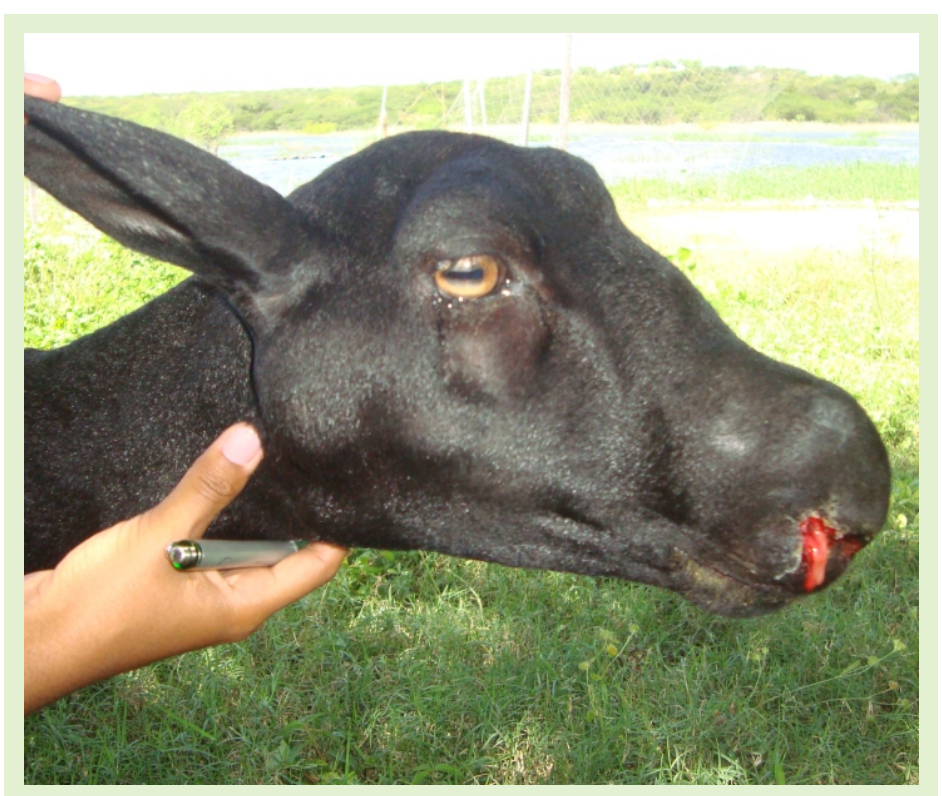

Figura 6. Ovino com pitiose na forma rinofacial com aumento do linfonodo parotídeo direito.

\section{PRINCIPAIS ENFERMIDADES DA CAVIDADE NASAL DE RUMINANTES}

\section{- Conidiobolomicose}

Conidiobolomicose é considerada uma micose emergente entre os ovinos ${ }^{44,53}$. A enfermidade deve-se a infecção da cavidade nasal por Conidiobolus incongru$u^{54,55}$, Conidiobolus lamprauges ou Conidiobolus corona$\mathrm{tus}^{2,47}$, fungos comumente encontrados em regiões de clima tropical e subtropical em áreas de alta umidade, como parasitas de insetos, em vegetais em decomposição e no solo ${ }^{24,56}$. A hipótese que os animais devam ser constantemente desafiados pelo agente para apresentar a enfermidadade ${ }^{57}$ tem sido considerada, não sendo necessária imunossupressão como uma condição obri- 
gatória à ocorrência da enfermidade entre os pequenos ruminantes ${ }^{24}$. C. lamprauges e C. coronatus foram espécies identificadas em surtos no Brasil ${ }^{38,58}$. Os agentes provocam lesões granulomatosas, principalmente na cavidade nasal, seios paranasais e tecidos adjacentes.

Em ovinos, o curso clínico da conidiobolomicose pode variar de períodos entre sete a vinte dias ${ }^{36}$ ou se estender até seis meses ${ }^{38}$. Os animais manifestam inicialmente sinais clínicos inespecíficos como redução do apetite, emagrecimento, apatia e secreção nasal serosa ou mucosanguinolenta, sendo a secreção a principal alteração relatada pelos produtores. Em casos avançados respiração ruidosa e dispneia inspiratória são sempre identificadas. $\mathrm{O}$ grave comprometimento respiratório ocorre principalmente devido a obstrução por massas granulomatosas que ocluem a cavidade nasal, o que justifica os sinais de hiperpneia e adoção de postura ortopneica ${ }^{3,38}$. Nos caprinos a secreção nasal serosa, dispneia e perda de peso foram os principais sinais clínicos observados em surto na Bahia. Adicionalmente, verificaram-se lesões cutâneas nodulares na orelha ${ }^{27}$.

A conidiobolomicose pode apresentar duas formas clínicas, rinofacial e rinofaríngea, dependendo do local onde as lesões se desenvolvem. $\mathrm{Na}$ forma rinofacial há acometimento da região rostral da cavidade nasal, conchas nasais, junção mucocutânea, lábio superior, pele da face, palato duro e maxila. A forma rinofaríngea ocorre com maior frequência e cursa com o envolvimento da região etmoidal, conchas nasais, seios paranasais e palato mole ${ }^{4,59}$. Nessa forma de apresentação pode-se observar exoftalmia unilateral associada a assimetria craniofacial. A exoftalmia ocorre como consequência da extensão da inflamação granulomatosa da cavidade nasal para seios paranasais e região retrobulbar, que projeta o globo ocular para fora da órbita ${ }^{3,22,59}$. Essa alteração pode ocasionar conjuntivite, ceratite, úlcera de córnea e perda da visão. Nas duas formas clínicas da doença os linfonodos parotídeos, retrofaríngeos, submandibulares e algumas vezes os préescapulares $^{3,38}$ podem estar aumentados de volume, como consequência da drenagem da lesão da cavidade nasal ou metástases (mais frequente na forma rinofaríngea). As alterações como as deformidades faciais, a exoftalmia e suas complicações associadas impressionam e incomodam os produtores, que consideram as lesões repugnantes, havendo inclusive registro de abandono da atividade.

Sinais neurológicos podem ser identificados nos casos de conidiobolomicose rinofaríngea devido à infiltração das lesões dos ossos etmoidais para a placa cribriforme, causando osteomielite com extensão para meninges e porções do cérebro ${ }^{3,4,59}$, como lobo frontal ${ }^{2,38}$ e com menor frequência o lobo temporal ${ }^{3}$. Os sinais identificados são o desvio lateral da cabeça ${ }^{21,47}$, pressão da cabeça contra objetos, andar em círculos, cegueira, ataxia e trismo ${ }^{2,38}$.

A assimetria crânio facial e a secreção nasal contribuíram para que casos de conidiobolomicose em ovinos fossem anteriormente diagnosticados como tumor etmoidal enzoótico ${ }^{60}$. Essa enfermidade é causada por um retrovírus, que provoca alterações neoplásicas na região etmoidal de pequenos ruminantes, que se assemelham as lesões causadas pelo Conidiobolus sp., entretanto, o tumor etmoidal enzoótico é raro no Brasil, havendo apenas um caso registrado ${ }^{61}$.

$\mathrm{Na}$ necropsia, em corte sagital da cabeça, é possível visualizar massas na cavidade nasal, cuja localização varia de acordo com a apresentação clínica rinofacial ou rinofaríngea. Essas massas caracterizam-se por serem amarelo-esbranquiçadas com superfície irregular ou finamente granular, por vezes multilobulada, firmes com focos friáveis, que, ocasionalmente, ao corte apresentam estrias acastanhadas ou avermelha$\mathrm{das}^{20,21,38,59}$. Na forma rinofaríngea podem apresentar dimensões variáveis ( 5 a $13 \mathrm{~cm}$ crânio-caudalmente e 3 a $8 \mathrm{~cm}$ dorso ventralmente) e estender-se do terço médio da cavidade nasal a placa cribriforme e adjacências. Geralmente causam obstrução e destruição de meatos, coanas nasais e infiltram placa cribriforme ${ }^{3,21,59}$ (Figura 7A). Em animais com exoftalmia, massas com 

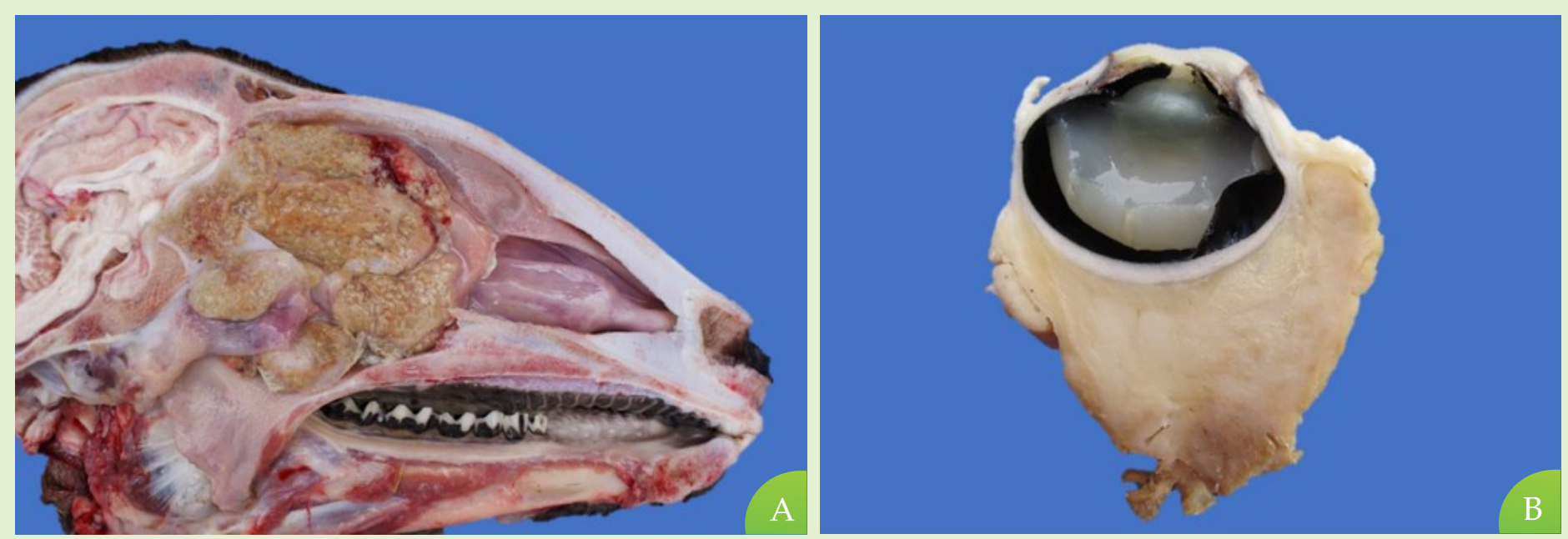

Figura 7. Conidiobolomicose rinofaríngea em ovino. (A) Secção sagital da cavidade nasal evidenciando massa irregular, multilobulada, brancoamarelada com foco avermelhado, estendendo-se da região etmoidal a porção média da cavidade nasal, invadindo região nasofaríngea e infiltrando placa cribriforme e (B) massa branco amarelada aderida ao globo ocular (Fotos cedidas pelo Laboratório de Patologia Animal, Hospital Veterinário Ivon Macedo Tabosa,UFCG).

aspecto semelhante às da cavidade nasal podem ser observadas na região retrobulbar preenchendo a cavidade orbital e aderida ao globo ocular e estruturas adjacentes (Figura 7B).

A forma rinofacial da doença é caracterizada por aumento de volume crânio rostral, que pode ser unilateral, ocorrendo como consequência de massa que estende-se da junção mucocutânea para o terço médio da cavidade nasal, causando obstrução das narinas e conchas nasais. Pode haver também envolvimento de lábio superior, palato duro e maxila. Úlceras extensas no palato duro com superfície lisa e coloração rósea, estendendo-se desde o pulvino dental até os primeiros pré-molares também são relatadas ${ }^{59}$.

Lesões extra nasais ocorrem principalmente associadas a conidiobolomicose rinofaríngea, e caracterizam-se por nódulos multifocais amarelados e firmes, que variam de 0,3 a $3 \mathrm{~cm}$ de diâmetro, vistas principalmente nos linfonodos (retrofaríngeos, supra escapulares, abomasais), pulmões e, menos frequentemente, no fígado, rins, coração, adrenais, intestino, língua e vesícula biliar ${ }^{3,4,21,22}$. Lesões ulcerativas, às vezes recobertas por material amarronzado e necrótico também podem ocorrer em abomaso, intestino, língua e vesícula biliar $^{16,24,54}$. Destaca-se que essas lesões ocorrem como consequência de disseminação hematógena e linfáti$\mathrm{ca}^{3,21,24}$. Na conidiobolomicose rinofacial as lesões extra nasais ocorrem principalmente nos pulmões.

O exame histopatológico revela que as massas correspondem a inflamação granulomatosa composta principalmente por macrófagos, às vezes associada a áreas de necrose com extensão variável, circundadas por células gigantes multinucleadas, plasmócitos, linfócitos e proliferação de fibroblastos ${ }^{3,4,22,59}$. Invasão vascular de hifas fúngicas, trombos arteriais, estão ocasionalmente presentes. Lesões com as mesmas características podem ser vistas em outros órgãos caracterizando disseminação hematógena ou linfática ${ }^{2,21,54}$.

Nas secções coradas pelo método de hematoxilina e eosina (HE), as hifas dificilmente são identificáveis, o que se observa são espaços circulares ou alongados envoltos por reação de Splendore-Hoeppli, observadas principalmente nas áreas de necrose. As hifas de Conidiobolus sp. são coradas fortemente em marrom por GMS e fracamente em rosa através do PAS e caracterizam-se por serem largas (5 a $30 \mu \mathrm{m}$ de largura), com paredes finas, pobremente septadas e ocasionalmente com dilatação balonosa na extremidade ${ }^{3,4,22,59}$. 
A reação em cadeia de polimerase (PCR) é um importante método para o diagnóstico de várias espécies de fungos devido à sua alta especificidade e sensibilidade $^{62}$. Recentemente foi desenvolvido um teste de PCR específico para C. lamprauges a partir de amostras de lesões de conidiobolomicose ovina ${ }^{63}$. $\mathrm{O}$ diagnóstico definitivo também pode ser obtido pela identificação de antígenos de C. lamprauges pela imunohistoquímica (IHQ), fato atribuído à sua capacidade de fornecer um diagnóstico rápido e preciso, em comparação aos cultivos micológicos que normalmente requerem maior tempo e experiência do micologista ${ }^{59}$. Nessa técnica recomenda-se sempre a utilização de controles positivos para identificação de reações cruzadas.

\section{- Pitiose Nasal}

A pitiose nasal deve-se a infecção da cavidade nasal pelo $P$. insidiosum ${ }^{43}$. De forma semelhante a conidiobolomicose pode também apresentar a forma rinofacial e rinofaríngea, sendo a rinofacial mais frequen$\mathrm{te}^{4,59}$. Em ruminantes, além da cavidade nasal ${ }^{8,30}, P$. insidiosum pode ocasionar lesões cutâneas ${ }^{8,64}$ e no sistema digestivo ${ }^{65}$. Surtos de pitiose nasal foram relatados em diferentes estados do país ${ }^{30,39,40,41}$. Da mesma forma que na conidiobolomicose não há indícios que a imunossupressão predisponha a pitiose nasal nos ovinos ${ }^{7,9,24}$.

O curso da enfermidade varia de sete a quinze dias ${ }^{4}$. Todavia existem relatos de cursos de até trinta $\operatorname{dias}^{30,40}$. Os animais acometidos apresentam caquexia (Figura 8A), secreção nasal serosanguinolenta fétida, espirros e dispnéia inspiratória ${ }^{40}$. Epistaxe pode ser observada e quando em estação o animal mantém a cabeça próxima ao solo ${ }^{41}$. $\mathrm{Na}$ forma rinofacial é perceptível um aumento de volume na porção rostral da cavidade nasal, levando frequentemente a deformação, por isso o nome popular da doença é "focinho de touro" (Figura 8B). Essa deformidade geralmente acontece de forma unilateral, comprometendo o vestíbulo nasal, a junção mucocutânea e lábios superiores ${ }^{30,40,59}$. Alopecia e nódulos podem ser observados na pele da porção dorsal do nariz ${ }^{43}$. Os linfonodos retrofaríngeos, parotídeos e pré-escapulares estão aumentados de volume ${ }^{40,43}$. Úlceras no palato duro e fístula oro-nasal, contendo tecido necrótico e restos de alimento, são frequentemente associadas a pitiose rinofacial ${ }^{43,59}$, entretanto, não são observadas em todos os casos da doença e ocasionalmente podem ser vistas na conidiobolomicose rinofacial $^{59}$.

As lesões macroscópicas observadas na cavidade nasal caracterizam-se por extensas áreas de necrose tecidual, com coloração variando de avermelhada a marrom amarelada, friáveis e fétidas. $\mathrm{Na}$ pitiose rinofacial essas lesões podem estender-se da região mucocutânea para o interior da cavidade nasal e em alguns casos estão associadas a perda de tecido ósseo nasal ${ }^{16,22,59}$ (Figura 9A) e tecido ósseo do palato, com substituição por massa necrótica, ocasionando as fístulas oronasais (Figura 9B).Linfonodos submandibulares e parotídeos estão quase sempre envolvidos e, ocasionalmente, granulomas são observados nos pulmões e glândulas paró$\operatorname{tidas}^{22,43,59}$.

$\mathrm{Na}$ pitiose rinofaríngea a lesão macroscópica consiste de massa ulcerada de coloração marrom avermelhada que pode estender-se da região etmoidal até a borda ventral da placa cribriforme ${ }^{59}$. No entanto, não foram relatados casos de meningoencefalite por extensão das lesões, como visto na conidiobolomicose rinofaríngea $^{3,9,21}$.

As lesões nasais de pitiose em ovinos são histopatologicamente caracterizadas por focos de necrose contendo imagens negativas de hifas circundadas por material radiado eosinofílico (reação de SplendoreHoeppli). Esses focos de necrose são rodeados por eosinófilos e neutrófilos e, mais externamente, por quantidade moderada de linfócitos, macrófagos, plasmócitos e células gigantes multinucleadas ${ }^{16,43,59}$. Hifas na luz de vasos sanguíneos associadas com trombos podem ser observadas $^{5}$. As hifas de $P$. insidiosum são fortemente marcadas por GMS e caracterizam-se por serem irre- 


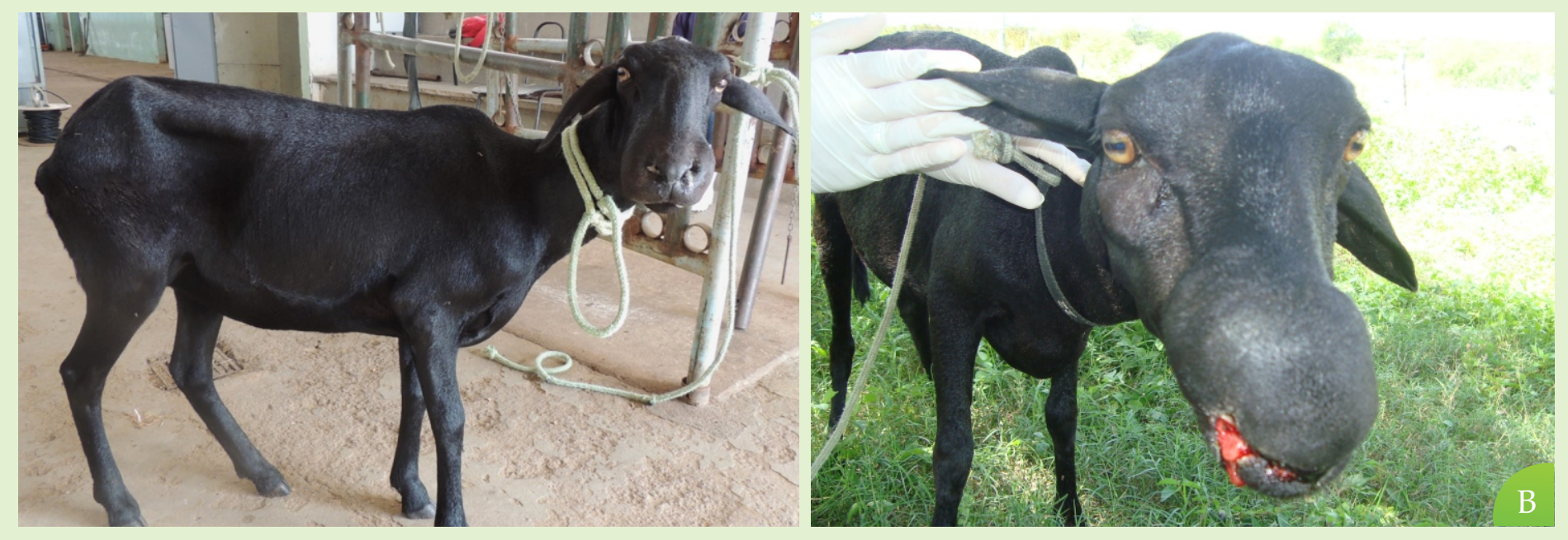

Figura 8. Pitiose rinofacial em um ovino. (A) Ovino magro com aumento de volume na porção rostral da cabeça e (B) secreção nasal sanguinolenta na narina direita, com aumento de volume na região rostral da cabeça, caracterizando o "focinho de touro" (Fotos cedidas pela Clínica Médica de Grandes Animais, Hospital Veterinário Ivon Macedo Tabosa, UFCG).

gulares, raramente septadas e ramificadas com paredes não paralelas, variando de 4 a 25 m de diâmetro ${ }^{16,43,59}$.

É importante ressaltar que os Kunkers, classicamente observados nas lesões macroscópicas de pitiose em equinos, não têm sido observados nos casos de pitiose em ovinos. Tais estruturas são caracterizadas por massas necróticas firmes, amarelas e granulares, com aspecto coralóide, que microscopicamente correspondem a fragmentos de hifas de $P$. insidiosum circundadas

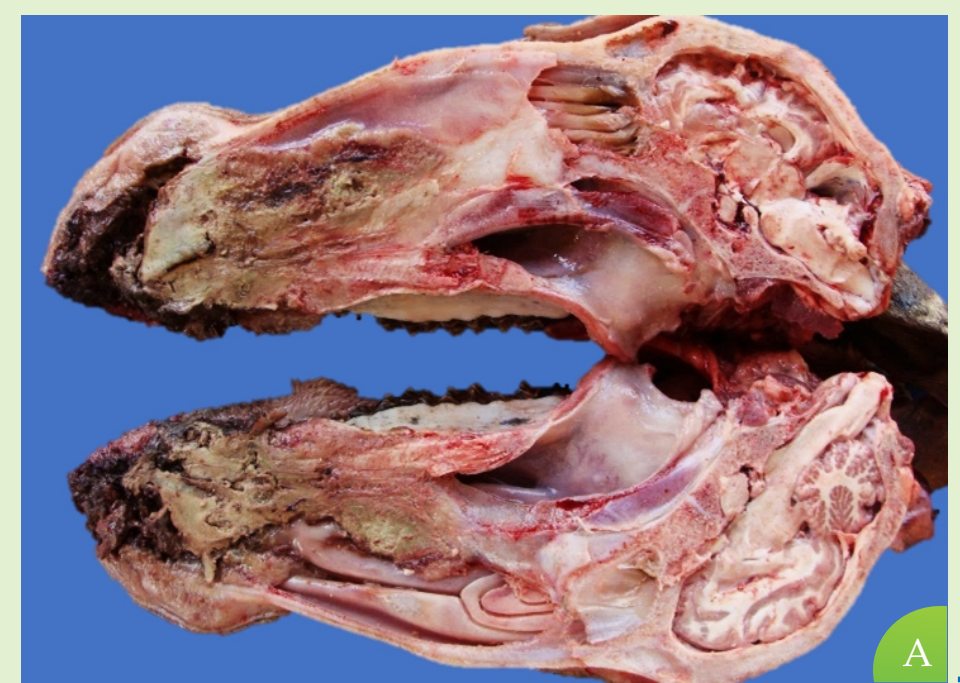

e embebidas por numerosos eosinófilos intactos, bem como detritos eosinofílicos abundantes. A diferença dessa apresentação macroscópica da doença entre as espécies tem sido relacionada ao tipo de resposta inflamatória, que nos equinos é essencialmente eosinofílica e necrosante ${ }^{66}$.

Técnicas moleculares também têm sido utilizadas para o diagnóstico de pitiose, mas podem revelar resultados falsos positivos em tecidos fixados em for-

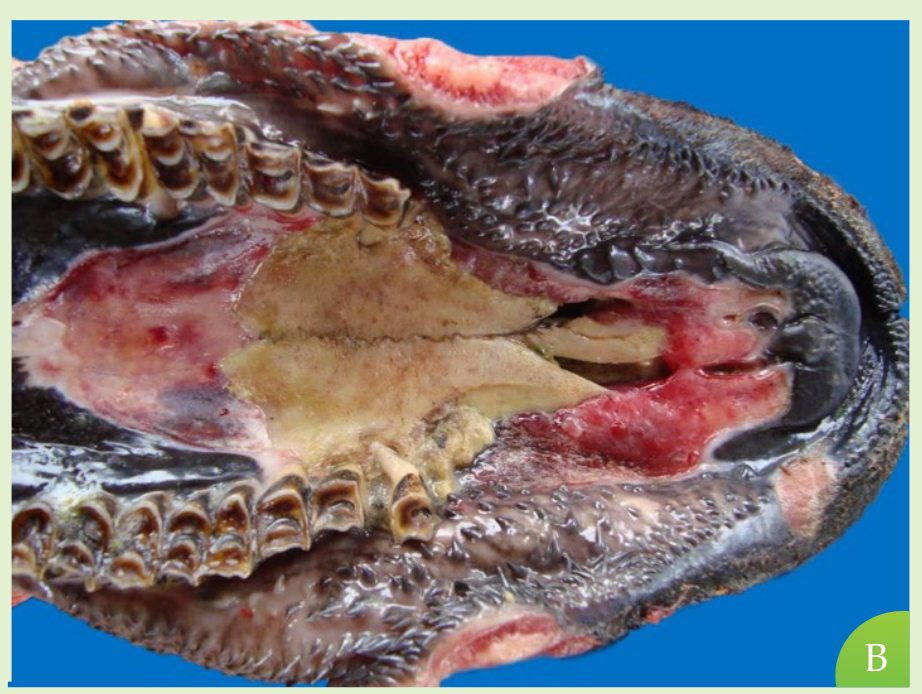

Figura 9. Pitiose rinofacial em ovino. (A) Corte sagital da cabeça, onde na porção rostral da cavidade nasal verifica-se necrose extensa severa (tecido marrom amarelado friável) que se estende da região mucocutânea para o interior da cavidade nasal e palato e (B) palato duro. Observa-se necrose, úlcera e fístula (Fotos cedidas pelo Laboratório de Patologia Animal, Hospital Veterinário Ivon Macedo Tabosa, UFCG). 
mol, uma vez que a formalina desnatura o $\mathrm{DNA}^{67}$. A técnica de imuno-histoquímica tem sido utilizada como método rápido e preciso nos casos de pitiose em animais ${ }^{68,69}$. O isolamento do patógeno mostra algumas controvérsias, é um processo lento e há risco de contaminação por bactérias secundárias, exigindo uma equipe treinada para zoosporogênese ${ }^{70}$.

O Ensaio Imunoenzimático (ELISA) indireto mostrou-se eficiente no diagnóstico de pitiose nasal em uma ovelha no Rio Grande do Sul, que apresentou títulos de anticorpos maiores do que o ponto de corte para P. insidiosum. Esse ovino também apresentou imunomarcação para $P$. insidiosum na imuno-histoquímica. $\mathrm{O}$ teste de ELISA indireto pode ser realizado a partir de amostras de sangue processadas para obtenção de soro por centrifugação (5.000 rpm durante dez minutos), armazenadas a temperatura de $-20{ }^{\circ} \mathrm{C}^{41}$.

\section{- Como diferenciar a conidiobolomicose e pitiose nasal em ovinos}

$\mathrm{Na}$ prática clínica nota-se grande dificuldade em lidar com o diagnóstico etiológico das rinites granulomatosas em ovinos, a exemplo da conidiobolomi- cose e pitiose nasal ${ }^{4,16,43,58}$, principalmente ao se considerar que a infecção nasal por Conidiobolus sp. e P. insidiosum apresentam características epidemiológicas e clínico-patológicas semelhantes ${ }^{2,43,59}$. Embora esses agentes produzam danos teciduais nas regiões rinofacial e rinofaríngea, alguns patologistas destacam que a localização e o tipo de lesão podem contribuir com a diferenciação das doenças ${ }^{59}$.

Para um diagnóstico presuntivo deve-se considerar que na pitiose a lesão usualmente encontra-se na região rinofacial e tem caráter necrosante, enquanto na conidiobolomicose as lesões são proliferativas, frequentemente localizadas na região rinofaríngea e na maioria dos casos estão associadas a exoftalmia, um dos mais notáveis sinais clínicos da conidiobolomicose ${ }^{59}$. Entretanto, há casos de conidiobolomicose com necrose, sugerindo que, possivelmente, essas variações na macroscopia das lesões possam estar associadas as espécies de Conidiobolus sp. envolvidas, evolução da doença e estado imunológico do animal. Essas características, embora importantes, não descartam a necessidade de coleta de material para exames auxiliares, tendo em vista que na conidiobolomicose rinofacial, embora menos frequente, pode ocorrer necrose demonstrando que o aspecto macroscópico da lesão não deve ser con-
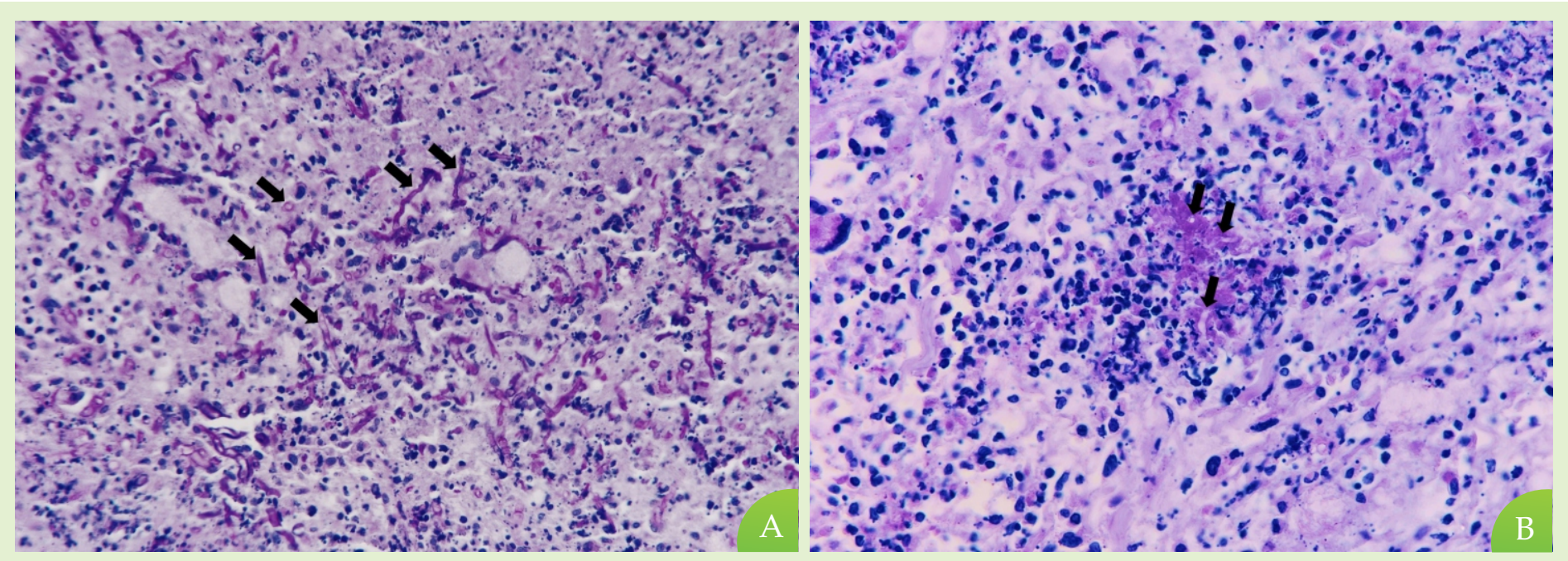

Figura 10. Histologia de corte de lesão em cavidade nasal de ovinos corados com Ácido Periódico de Schiff(PAS). (A) Hifas de Conidiobolus sp. fortemente impregnadas em rosa (setas) e (B) imagens negativas de hifas de Pythium insidiosum (setas). Objetiva de 40x. 
siderado de forma isolada.

As características morfotintoriais dos agentes também podem colaborar na diferenciação das enfermidades. Embora as hifas de P. insidiosum e Conidiobolus sp. sejam fortemente marcados na impregnação por GMS, as hifas de Pythium insidiosum não são observadas na coloração de PAS (Figura 10), possivelmente a ausência de quitina na parede celular de $P$. insidiosum seja responsável por essa ausência de marcação no PAS, auxiliando o diagnóstico diferencial com Conidiobolus $\mathrm{sp.}^{22,59}$

Associadas a essas características do agente, chama a atenção que nos casos de conidiobolomicose há uma maior quantidade de células gigantes multinucleadas quando comparadas aos casos de pitiose ${ }^{22,59}$. O material de Splendore-Hoeppli também parece diferir, com um padrão amorfo na infecção por Conidiobolus sp.e um padrão granular na infecção por P. insidiosum.

\section{- Criptococose Nasal}

A criptococose é uma micose potencialmente fatal que pode acometer diversas espécies de ruminantes, resultando em danos sistêmicos ${ }^{71}$, pulmonares ${ }^{72}$, neurológicos ${ }^{73}$ e mastites crônicas ${ }^{74}$. O Cryptococcus sp. pode também ocasionar alterações no trato respiratório superior de pequenos ruminantes, entretanto, a infecção é considerada rara. Existe descrição da infecção da cavidade nasal de ovinos ${ }^{5,6}$, pelas espécies Cryptococcus gattii ${ }^{33}$ e Cryptococcus neoformans ${ }^{5}$, e o último agente também foi encontrado lesionando a narina de uma cabra ${ }^{75}$.

O curso da doença é variável, entre quinze ${ }^{6}$ dias e dois meses ${ }^{33}$. Os animais apresentam emagrecimento, dispneia acentuada, secreção nasal sanguinolenta intensa $^{33}$, tosse e espirros ${ }^{75}$. $\mathrm{O}$ agente produz um aumento de volume assimétrico na cavidade nasal, sendo possível observar a exteriorização de uma massa pedunculada com aspecto necro hemorrágico obstru- indo a narina acometida ${ }^{5,6,33}$ (Figura 11A). Há aumento dos linfonodos regionais na cabeça ${ }^{6}$. Com a progressão da doença pode haver uma alopecia na região dorsal da cavidade nasal e durante a palpação verifica-se um amolecimento da estrutura dos ossos nasais. Pode-se perceber dispneia inspiratória, tosse esporádica, ruídos respiratórios e momentos de apneia ${ }^{6}$.A lesão da cavidade nasal pode se estender às leptomeninges e tecido nervoso e o animal pode vir a apresentar cegueira ${ }^{5}$.

A reação tecidual na criptococose varia de inflamação granulomatosa intensa a inflamação mínima ou ausente com quantidade abundante de leveduras. A destruição tecidual resulta de necrose compressiva, causada por massas de leveduras encapsuladas ${ }^{76}$. Apesar da infecção por Cryptococcus sp. incitar resposta inflamatória granulomatosa, em alguns casos pode não ocorrer a formação de nódulos amarelados, característicos da inflamação granulomatosa ${ }^{76}$. Nos casos de rinite descritos em ovinos, na necropsia observaram-se massas claras, acinzentadas ou avermelhadas, irregulares, às vezes aparentes na narina, ocupando o vestíbulo nasal e estendendo-se à região etmoidal ${ }^{6,33}$ (Figura 11B).

Embora haja semelhança com pitiose nasal, devido a assimetria unilateral e o acometimento de linfonodos superficiais, o aspecto pendular e aparente da lesão pode auxiliar no diagnóstico diferencial com essa patologia e outras rinites infecciosas. Nesses casos recomenda-se a realização de exame citológico, pois permite a identificação de forma rápida de leveduras de Cryptococcus sp ${ }^{33}$.

A característica da estrutura leveduriforme do Cryptococcus sp., com cápsula constituída de mucopolissacarídeos confere aspecto acinzentado e gelatinoso a maioria das lesões macroscópicas ocasionadas por esse agente $^{73}$. É sugerido que essa cápsula impede o reconhecimento da levedura pelos fagócitos bloqueando a migração de leucócitos para o local da replicação fúngi$\mathrm{ca}^{77}$. Entretanto, cápsulas pouco desenvolvidas resultam em resposta imune mediada por células ativas, 



Figura 11. Criptococose nasal em um ovino. (A) Aumento de volume unilateral na porção rostral da cabeça e massa pedunculada de aspecto necro hemorrágico aparente na narina direita e (B) massa brancacenta com área necro hemorrágica estendendose do vestíbulo nasal direito ao osso etmoidal, causando obstrução da cavidade nasal direita. (Fotos cedidas pelo Dr. Vitor Santiago de Carvalho, Médico veterinário do Centro de Desenvolvimento da Pecuária, Universidade Federal da Bahia CDP/UFBA).

podendo ocorrer formação de granulomas bem defini$\operatorname{dos}^{76}$.

O diagnóstico de criptococose pode ser estabelecido com base nos dados clínico-epidemiológicos, citológicos, anatomopatológicos, confirmados através de cultivo e isolamento e $\mathrm{PCR}^{33,78}$.

A citologia pode ser realizada a partir de esfregaços de materiais destinados à biópsia e de secreções. A punção aspirativa por agulha fina (PAAF) também se mostra eficiente para o diagnóstico de criptococose e representa um método prático e de rápida execução. No exame citológico é possível observar numerosos blastoconídios ovais a arredondados, pleomórficos, por vezes em brotamento, de diferentes tamanhos (Figura 12), envoltos por espessa cápsula lipídica não corada por coloração hematológica do tipo Romanoswsky modificado, compatíveis com infecção por Cryptococcus sp. $^{33,79}$.

O exame histopatológico também auxilia no diagnóstico, e uma das colorações mais empregadas é
Mucicarmim de Meyer, com a qual observa-se a cápsula corada em vermelho, facilitando o reconhecimento de Cryptococcus sp. na lesão, principalmente de amostras hipocapsuladas $^{33,79}$.

$\mathrm{Na} \mathrm{HE}$, evidenciam-se leveduras arredondadas, compostas por um halo claro, em geral, não corado (cápsula da levedura), circundando uma estrutura levemente basofílica redonda, por vezes levemente alongada (célula da levedura), livres no tecido, que podem estar associadas a inflamação granulomatosa discreta ou acentuada. No interior de algumas células pode ser visto material granular levemente eosinofílico (núcleo da célula da levedura). As cápsulas das leveduras exibem diferentes espessuras e, por não corarem, conferem ao tecido um aspecto vacuolizado, conhecido como "lesão em bolha de sabão". O estudo histopatológico permite o diagnóstico somente de criptococose, pois a distinção das espécies, Cryptococcus neoformans ou Cryptococcus gatti, só é possível através de técnicas moleculares utilizando inclusive tecidos lesionados emblo- 



Figura 12. Exame citológico (coloração do tipo Romanoswsky).(A e B) Estruturas leveduriformes com cápsula mucoide espessa e não corada, com estruturas internas discretamente granulares compatíveis com Cryptococcus sp. (setas). Objetiva de 100x e imersão (Fotos cedidas por Jefferson da Silva Ferreira). cados em parafina, bem como cultivo e isolamento do agente $^{33,78,79}$.

\section{- Aspergilose Nasal}

Aspergillus embora seja um microrganismo encontrado facilmente no ambiente, e que penetre no seu hospedeiro a partir da inalação ${ }^{80}$, rinites por este agente são consideradas raras, havendo apenas um relato em caprino ${ }^{7}$, causado pelo $A$. niger, e um em bovino ${ }^{81}$, cuja espécie não foi identificada. $O$ agente também pode causar pneumonia, mastite e traqueíte em ruminantes ${ }^{82,83,84}$,resultando em morte dos animais acometidos. Devido a característica oportunista do gênero Aspergillus geralmente as infecções estão associadas a fatores imunossupressores, incluindo o uso indiscriminado de antimicrobianos, estresse pós-parto, doenças primárias como rinotraqueíte infecciosa, diarreia viral bovina ${ }^{85,86,87}$ e febre catarral maligna.

A aspergilose nasal é uma enfermidade de curso crônico. Dificuldades respiratórias foram identificadas em caprino por períodos de três meses antes do encaminhamento ao hospital veterinário. $\mathrm{Na}$ avaliação clínica o animal apresentava severa dispneia inspiratória, respiração ruidosa e descarga nasal mucopurulenta. Nódulos foram identificados no plano nasal dorsal e orelha, sendo também identificada uma área despigmentada na comissura ventral da narina direita ${ }^{7}$.

O estudo histológico das lesões cutâneas e da cavidade nasal demonstrou piogranulomas multifocais a coalescente com áreas centrais de necrose circundadas por neutrófilos, macrófagos, linfócitos, raras células gigantes multinucleadas e tecido conjuntivo fibroso. Imagens negativas de hifas puderam ser observadas associadas a áreas de necrose ${ }^{7}$.

Em bovinos, a infecção por Aspergillus sp. afetando o trato respiratório superior é rara, entretanto, foi diagnosticada recentemente na região semiárida da Paraíba, concomitante à febre catarral maligna. As lesões macroscópicas observadas foram áreas erosivas e ulcerativas nas conchas e meatos nasais da cavidade nasal (Figura 13A) e superfície da traqueia e brônquios recobertos por exsudato amarelado e material esbranquiçado, às vezes acinzentado, de aspecto flocular ${ }^{81}$ (Figura 13B). No exame histopatológico observou-se rinite, traqueíte e bronquite fibrinonecrótica moderada associada a hifas e conidióforos intralesionais.

O diagnóstico histomorfológico de aspergilose nas vias aéreas e pele é facilitado pela visualização dos conidióforos, que são estruturas características desse gênero $^{88,89}$,facilmente visualizadas no exame histopatológico, mas que não são observados em todos os casos da doença, pois a formação dos mesmos ocorre unicamente quando as hifas estão expostas a grande quantidade de oxigênio ${ }^{90}$. No caso descrito no caprino não foram observados conidióforos. Pela coloração do PAS e GMS hifas e conidióforos coram-se em rosa e marrom, respectivamente.

A confirmação do agente etiológico pode ser realizada através da imuno-histoquímica, utilizando 



Figura 13.Aspergilose nasal em bovino. (A) Secção sagital da cavidade nasal evidenciando em conchas e meatos nasais exsudato amarelado, com material esbranquiçado e acinzentado, flocular e (B) mucosa da traqueia e brônquios apresentando exsudato amarelado e material esbranquiçado (Fotos cedidas pelo Laboratório de Patologia Animal, Hospital Veterinário Ivon Macedo Tabosa,UFCG).

anticorpo anti-Aspergillus spp. e método estreptavidina-biotina-fosfatase alcalina, com imunomarcação das hifas em vermelho ${ }^{69}$. Os conidióforos geralmente são fracamente imunomarcados ou não imunomarcados, possivelmente devido às diferenças existentes na composição antigênica das diferentes fases de desenvolvimento dos fungos ${ }^{91}$. Para identificar a espécie envolvida pode-se associar o exame histopatológico e microbiológico.

\section{- Prototecose Nasal}

Prototecose nasalé uma enfermidade raramente diagnosticada, de curso crônico e progressão lenta, com evolução de até dez meses, podendo ser confundida com outras enfermidades da cavidade nasal, principalmente com infecções fúngicas ${ }^{92}$. Prototheca wickerhamii, classificada entre as algas inferiores, foi isolada em dois casos de rinites em caprinos ${ }^{9,29 .}$ Os sinais clínicos são perda de peso, dispneia inspiratória, secreção nasal mucopurulenta e nódulos nos lábios superiores, junção muco-cutânea e plano dorsal do nariz, que com a evolução da doença podem aumentar de tamanho e ulcerar $^{9,29}$ (Figura 14A). Postura ortopneica e grande esforço durante a inspiração e expiração são observados no estágio final da doença ${ }^{29}$.

Prototecose nasal em caprinos tem sinais clínicos, localização e aspectos macroscópicos das lesões semelhantes aos da conidiobolomicose e aspergilose nasal. O diagnóstico diferencial dessas afecções só é possível através do exame histopatológico e microbiológico ${ }^{7,27,29,93}$. Nas três afecções os achados de necropsia consistem em aumento de volume no plano nasal dorsal (Figura 15A) e, após corte sagital da cabeça, verificam-se massas bilaterais irregulares e amareladas que podem estender-se das narinas as conchas nasais, meato e septo nasal (Figura 14B e 15B). Úlceras são ocasionalmente observadas na mucosa nasal ${ }^{7,27,29}$. Nódulos com até $3 \mathrm{~cm}$ de diâmetro podem ser vistos no tecido subcutâneo acima do osso nasal e pele da orelha, nos casos de conidiobolomicose e aspergilose ${ }^{7,27,29}$ (Figura $15 \mathrm{C}$ e D). Na prototecose os nódulos no plano nasal dorsal do nariz também estão presentes, entretanto estão associados também a nódulos com superfície ulcerada vistos na junção mucocutânea e vestíbulo nasal $^{7,27}$. A ausência de lesões em outros órgãos, além 

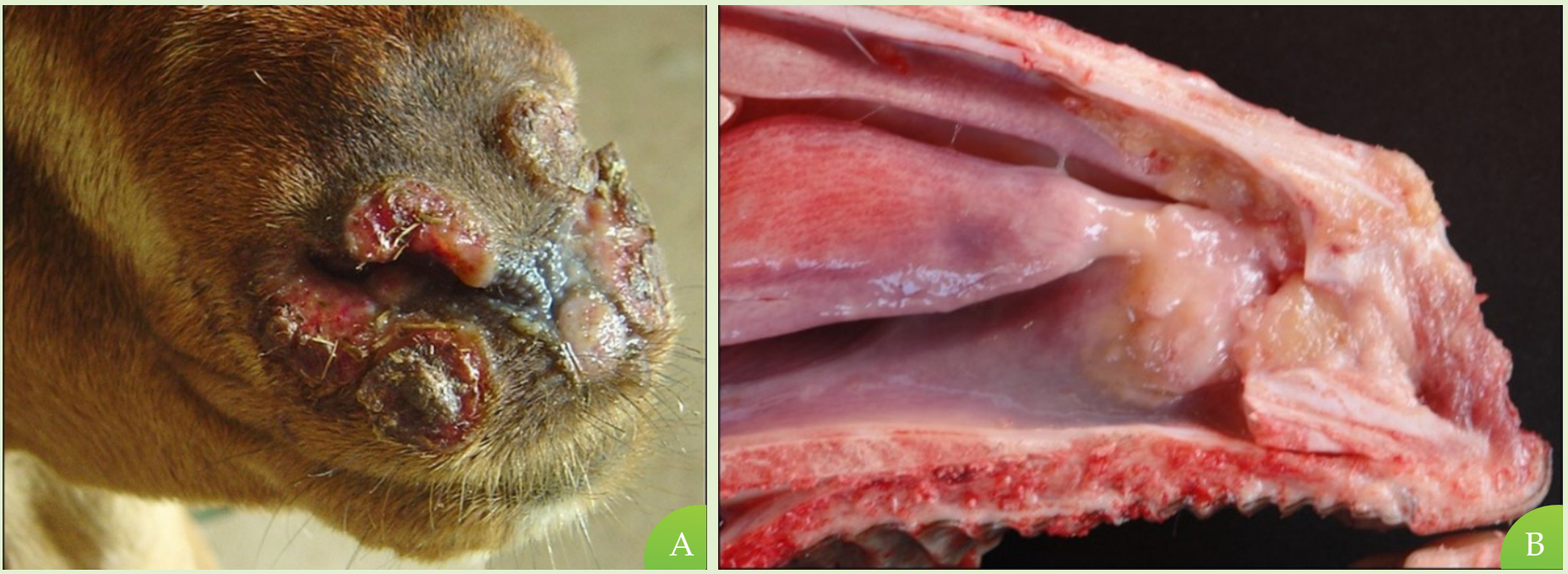

Figura 14. Prototecose nasal em caprino. (A) Observam-se nódulos ulcerados no vestíbulo nasal, junção muco-cutânea do nariz e lábio superior e (B) secção sagital da cavidade nasal evidenciando múltiplas massas irregulares no assoalho da mucosa nasal estendendo-se a porção inicial dos meatos (Fotos cedidas pelo Laboratório de Patologia Animal, Hospital Veterinário Ivon Macedo Tabosa, UFCG).

daqueles do sistema respiratório superior, é uma semelhança entre a prototecose e a aspergilose nasal ${ }^{7}$.

O diagnóstico definitivo de prototecose nasal é possível com a utilização de métodos de cultivo e avaliação histopatológica ${ }^{94}$. Nesses casos, histologicamente observam-se dermatite e rinite granulomatosa associada a miríades de esporângios, contendo esporangiósporos internamente. É característico de $P$. wickerhamii a presença de esporangiósporos com um endósporo central arredondado, rodeado por uma coroa de endósporos, descrito como semelhantes à mórula, flor de margarida ou framboesa ${ }^{9}$.A observação dessa estrutura no exame histopatológico e colorações histoquímicas especiais como GMS e PAS, permite o diagnóstico de Prototecose.
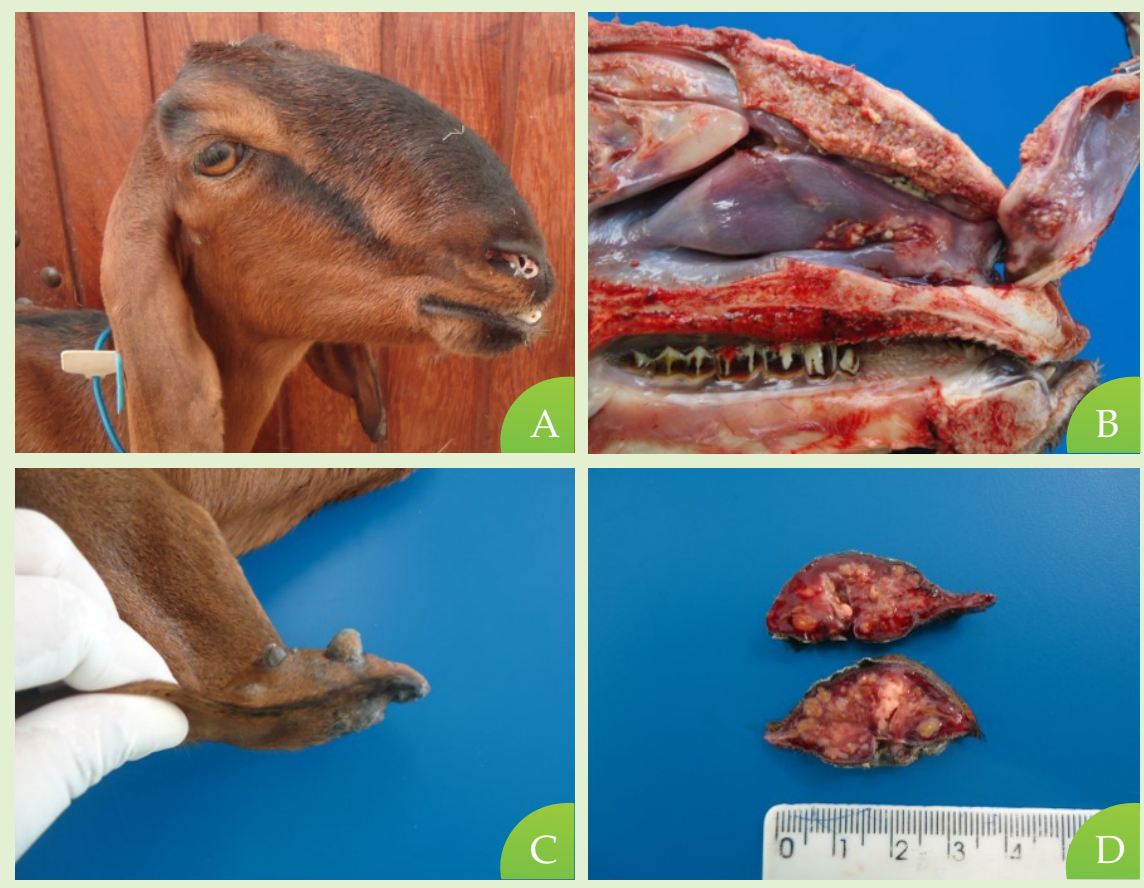

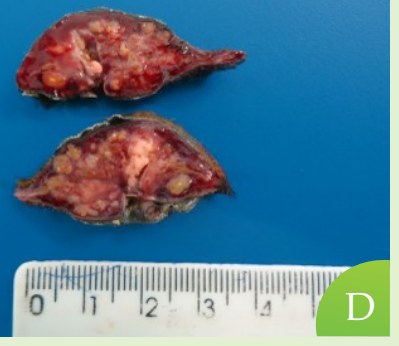

Figura 15. Conidiobolomicose rinofacial em caprino. (A) Aumento de volume no plano dorsal do nariz, (B) secção sagital da cavidade nasal evidenciando no septo nasal material amarelo amarronzado, com superfície irregular e granular e na concha nasal ventral e porção inicial do meato há múltiplos nódulos amarelados e (C e D) lesões cutâneas nodulares na orelha, que ao corte revelam, múltiplos pontos amarelados (Fotos cedidas pelo Setor de Patologia Veterinária, Universidade Federal do Recôncavo da Bahia). 


\section{- Oestrose}

A oestrose é uma miíase cavitária de caprinos e ovinos causada pelo desenvolvimento de larvas da mosca Oestrus ovis, também conhecida como "bicho da

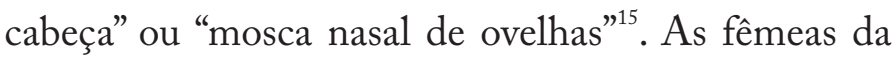
mosca Oestrus ovis são do tipo larvíparas e depositam suas larvas de primeiro estágio em vôos rápidos ao redor das narinas dos animais ${ }^{95}$. As larvas migram para a cavidade nasal, seios frontais e maxilares, às vezes até a base dos chifres, onde realizam duas ecdises transformando-se em larvas de terceiro estágio (L3), que causam irritação, inflamação e obstrução das passagens aéreas $^{96}$, caracterizando a rinite parasitária.

Os sinais clínicos da oestrose se iniciam quando as moscas estão na época de larviposição. Os animais ficam agitados, com movimentação excessiva da cabeça, apresentam discreta secreção nasal mucosa e alguns animais podem ser vistos pressionando as narinas contra os outros ou mesmo no solo ${ }^{32,96}$. Uma vez instalada na narina há migração das larvas na cavidade nasal que causa irritação crônica e provoca uma reação

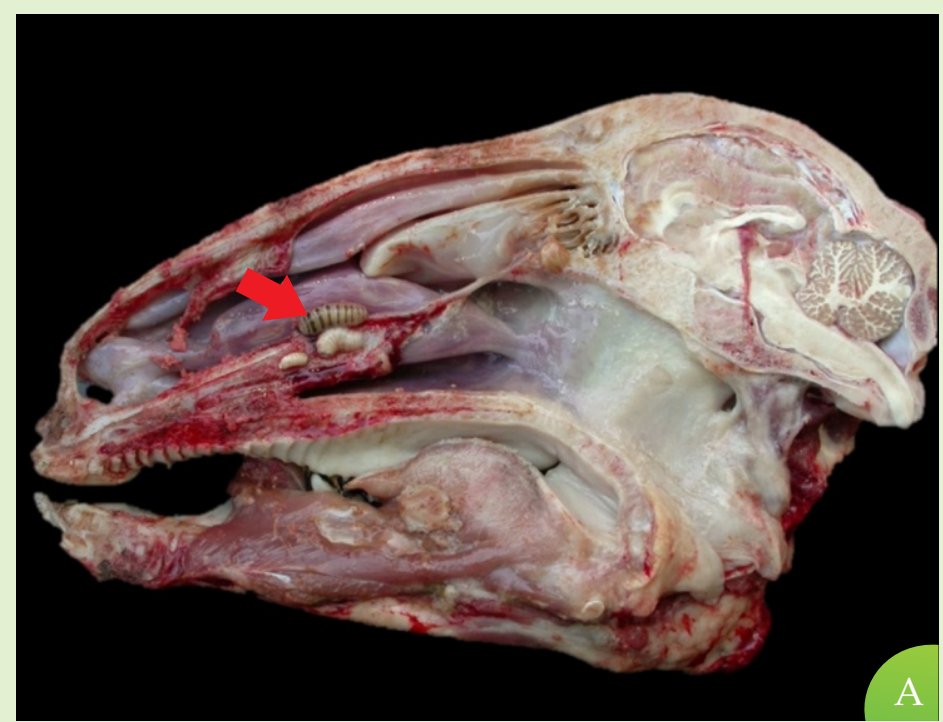

inflamatória, devido a presença de espinhos nas cutículas das larvas e a liberação de enzimas que lesam diretamente a mucosa ${ }^{97,98}$. Nessa fase observa-se espirros e secreção nasal mais evidente, que passa a ter aspecto seromucoso e nos casos mais severos mucopurulento, podendo ocasionalmente estar tingida com sangue ${ }^{99}$. Secreções purulentas foram relacionadas com o maior número de larvas de Oestrus ovis na cavidade nasal de ovinos e a gravidade mostrou-se maior quando as larvas eram encontradas vivas ${ }^{100}$.

As afecções parasitárias nas narinas podem deixar os indivíduos susceptíveis a instalação de quadros de broncopneumonias infecciosas ${ }^{99}$, com consolidação crânio-ventral dos pulmões ${ }^{32}$. Raramente, quando os hospedeiros são fortemente infectados, larvas de Oestrus ovis penetram a caixa craniana através da placa etmoidal, causando meningite bacteriana direta ou secundária, nesses casos, sinais clínicos como ataxia, nistagmo e amaurose podem ser observados ${ }^{96}$.

A oestrose, por ser uma doença que geralmente não causa a morte dos animais, não é frequentemente diagnosticada nos laboratórios de patologia ${ }^{16,22}$. Larvas

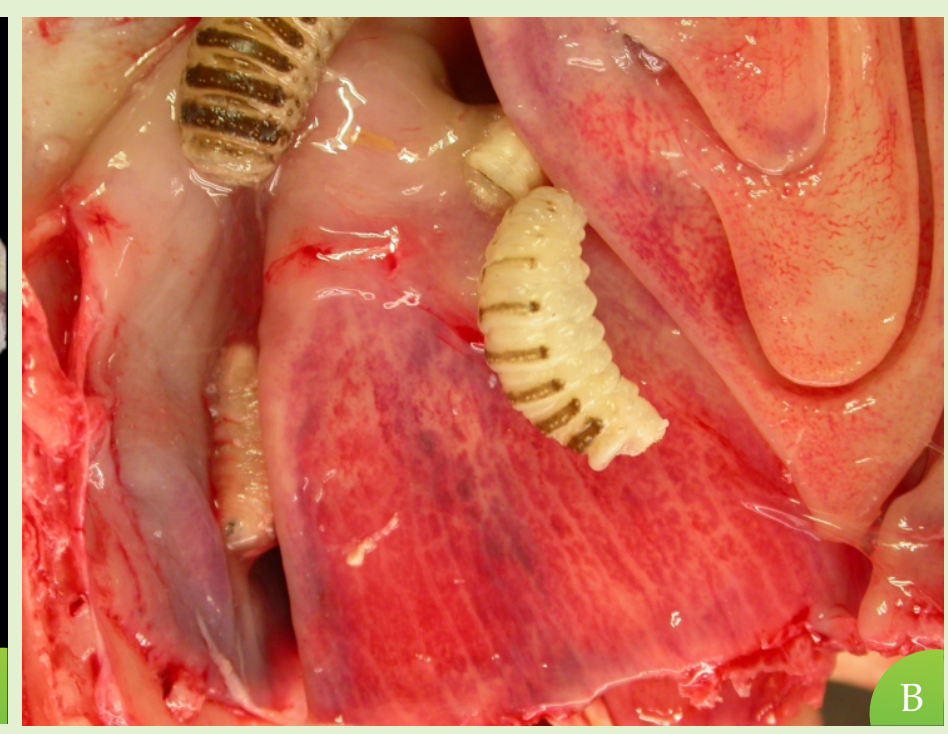

Figura 16. Oestrose em um ovino. (A) Secção sagital da cabeça evidenciando hiperemia das conchas nasais dorsal e ventral e larvas de Oestrus ovis (seta) e (B) larvas de Oestrus ovis na cavidade nasal e hiperemia acentuada de concha nasal (Fotos cedidas pelo Dr. Luiz Miguel Ferrer Mayayo (Departamento de Patologia Animal, Universidad Zaragoza, Espanha). 
de O. ovis podem ser facilmente detectadas se a cabeça é cortada de modo a expor os meatos da cavidade nasal (Figura 16A). O número de larvas observado pode ser variável (24 a 94 larvas em altas infestações), sendo encontradas principalmente nos seios paranasais ( $\mathrm{Fi}^{-}$ gura 16B) e esporadicamente no divertículo cornual do seio frontal, concha etmoidal, coanas nasais, cavidade oral e orofaringe ${ }^{22}$. A maioria dos ovinos e caprinos não apresenta alterações patológicas significativas. Entretanto, lesões macroscópicas como sinusite, hiperemia de conchas nasais e coanas foram relatadas em ovinos com quadro clínico de dispneia ${ }^{22}$.

\section{- Granuloma Nasal em Bovinos}

O termo granuloma nasal bovino tem sido utilizado para caracterizar lesões nodulares, inflamatórias, de tamanhos variados, nas narinas e cavidade nasal. Embora tenha sido frequentemente associado a rinite alérgica ou atópica, fungos e bactérias também causam lesões granulomatosas com apresentação clínica e macroscópicas semelhantes. Independente da etiologia o granuloma nasal em bovinos ocorre esporadicamente.

No Brasil há registros do granuloma nasal de origem alérgica (rinite alérgica) nos estados do Rio Grande do $\mathrm{Su}^{35}$ e Pernambuco ${ }^{16}$. A rinite alérgica tem sido atribuída a reações repetidas de hipersensibilidade tipo $\mathrm{I}^{34,101}$ e uma predisposição hereditária também é $\operatorname{proposta}^{102}$. A doença inicia-se com secreções nasais, que podem apresentar estrias de sangue, além de congestão na mucosa nasal. Posteriormente observa-se crostas nas narinas e prurido, que leva os animais a esfregarem as narinas em árvores, causando epista$\mathrm{xe}^{12,35}$. O trauma da região pode levar a deformações secundárias, provocando assimetria e deformações na mucosa da cavidade nasal devido a inflamação ${ }^{35}$. Nos estágios crônicos podem ser visualizados, na narina e agrupados na mucosa nasal, múltiplos nódulos de consistência firme, brancoalaranjados, variando de 0,5 a 1 $\mathrm{cm}^{\text {de diâmetro }}{ }^{16,35}$. Os nódulos não contribuem significativamente para a obstrução nasal, porque persistem durante a remissão clínica ${ }^{34}$.É provável que a obstrução seja causada, em sua maior parte, por congestão das veias cavernosas da lâmina própria ${ }^{34}$. As alterações inflamatórias agudas ocorrem episodicamente e causam as crises de obstrução nasal com corrimento e prurido.

Apesar de macroscopicamente cursar com nódulos na mucosa nasal, semelhantes aos granulomas de natureza infecciosa, a etiologia alérgica pode ser indicada pelo grande número de eosinófilos nos esfregaços do corrimento nasal e nas lesões histológicas ${ }^{35}$. $\mathrm{O}$ caráter sazonal da doença e o desaparecimento passageiro dos sinais após o tratamento com corticosteroides, também auxilia na realização do diagnóstico diferencial $^{16,35}$

Microscopicamente, observa-se hiperplasia e metaplasia escamosa do epitélio respiratório de revestimento e das glândulas, fibroplasia, proliferação vascular e infiltração linfóide da lâmina própria. Frequentemente há grande número de eosinófilos e mastócitos no infiltrado inflamatório ${ }^{34,103}$.

Granuloma nasal associado a infecção pelo fungo Coccidioides immitis foi relatado em bovino no Rio Grande do Sul. As principais alterações identificadas no exame físico foram nódulos na entrada das narinas e proliferações nodulares, com área de até 3 × 3 x 0,5 $\mathrm{cm}$, e superfície irregular obstruindo parcialmente as porções proximal e média de ambas as cavidades nasais ${ }^{104}$.

\section{- Rinosporidiose}

A rinosporidiose nasal é uma doença crônica, granulomatosa, que cursa com a formação de pólipos na cavidade nasal. A enfermidade tem na sua etiologia o Rbinosporidium seeberi ${ }^{13}$ e possui curso clínico variável, de duração de uma semana a seis meses. A inspeção das narinas com ajuda de uma fonte de luz permite a obser- 
vação dos pólipos. Esses pólipos sangram facilmente, usualmente são unilaterais, mas podem ocorrer bilateralmente. Epistaxe é frequentemente relatada pelo produtor. Os bovinos acometidos apresentam secreção nasal mucopurulenta, às vezes acompanhada de estrias de sangue, respiração ruidosa, tosse ou espirros ${ }^{14}$. Dependendo do tamanho dos pólipos, que podem variar de 2 a $6 \mathrm{~cm}$, os animais podem apresentar dispneia inspiratória progressiva e acentuada. A excisão cirúrgica da lesão é curativa, mas pode haver recidivas ${ }^{105}$.

Biópsia para cultura e histopatologia é indicada para identificação do agente. Macroscopicamente os pólipos são sésseis ou pedunculados, macios, róseos ou amarelo esbranquiçados, com pequenas granulações esbranquiçadas e irregulares que correspondem aos esporângios do R. seeberi ${ }^{16,106}$.

No exame histopatológico os pólipos nasais correspondem a infiltrado inflamatório granulomatoso na mucosa do septo nasal, associado a miríades de esporângios com endósporos em seu interior com morfologia semelhante a $R$. seeberi em várias fases de maturação.

Devido às características clínicas e macroscópicas semelhantes ao granuloma nasal, de origem alérgica e fúngica por $C$. immitis, é importante considerar essas patologias como diagnóstico diferencial da rinosporidiose $^{35,104}$.

\section{- Envolvimento da Cavidade Nasal em Infecções por Actinobacillus lignieresii e Actinomyces bovis}

Actinobacillus lignieresii causa infecção piogranulomatosa de tecidos moles na cabeça, pescoço ou outras áreas do corpo. Actinomyces bovis ocasiona quadros de osteomielite granulomatosa na mandíbula e maxila de bovinos ${ }^{107,108}$. Esses dois agentes podem, em condições mais raras, ocasionar obstruções devido a formação de granulomas nasais ou secundária a osteomielite granulomatosa da maxila por $A$. bovis.
Os dois agentes podem ocorrer em qualquer parte das vias aéreas superiores porque estão presentes na cavidade oral e na faringe. Quando ocorre lesão da mucosa e a infecção dos tecidos moles ambos os organismos produzem granulomas, que geralmente são unilaterais e aparentes nas narinas. Os granulomas podem estar associados a lesões causadas por sondas nasais, alimentos fibrosos e corpos estranhos e se caracterizam por massas vermelhas, elevadas que sangram facilmente. $\mathrm{O}$ aumento progressivo dessa massa leva a dispneia inspiratória, podendo haver oclusão completa da narina (Figura 17). Secreção nasal é encontrada em pacientes com granulomas localizados mais profundamente na cavidade nasal, laringe, faringe ou traqueia ${ }^{109}$.

Um caso de granuloma nasal associado ao $A$. bovis foi relatado em búfalo, os principais sinais clínicos observados foram a presença de massa ocluindo toda a narina, secreção nasal densa, esbranquiçada e mucosa, dispneia inspiratória, respiração ruidosa e extensão da cabeça e pescoço ${ }^{110}$.

O granuloma nasal por $A$. bovis e $A$. ctinobacillus lignieresii pode ser confundido com outras infecções bacterianas e neoplasias. Dessa forma o adequado diagnóstico é fundamentado nos exames microbiológicos, citológicos e histopatológicos em virtude da similaridade da apresentação macroscópica das enfermidades.

A osteomielite granulomatosa, provocada pelo A. bovis, pode ocasionar deformidade da cabeça devido a proliferação óssea do maxilar direito e esquerdo, afetando secundariamente a cavidade nasal. Em dois casos relatados em bovinos no Rio Grande do Sul, extensas áreas inflamatórias causaram destruição de parte dos cornetos nasais e obstrução quase que total da cavidade com desvio nasal contralateral ${ }^{111}$, o que justifica a inclusão da actinomicose nas doenças que afetam a cavidade nasal.

A lesão macroscópica caracteriza-se por proliferação óssea com múltiplos nódulos amarelos com aspecto caseoso, circundados por finos septos de tecido ósseo. No centro dessas áreas podem ser observados 

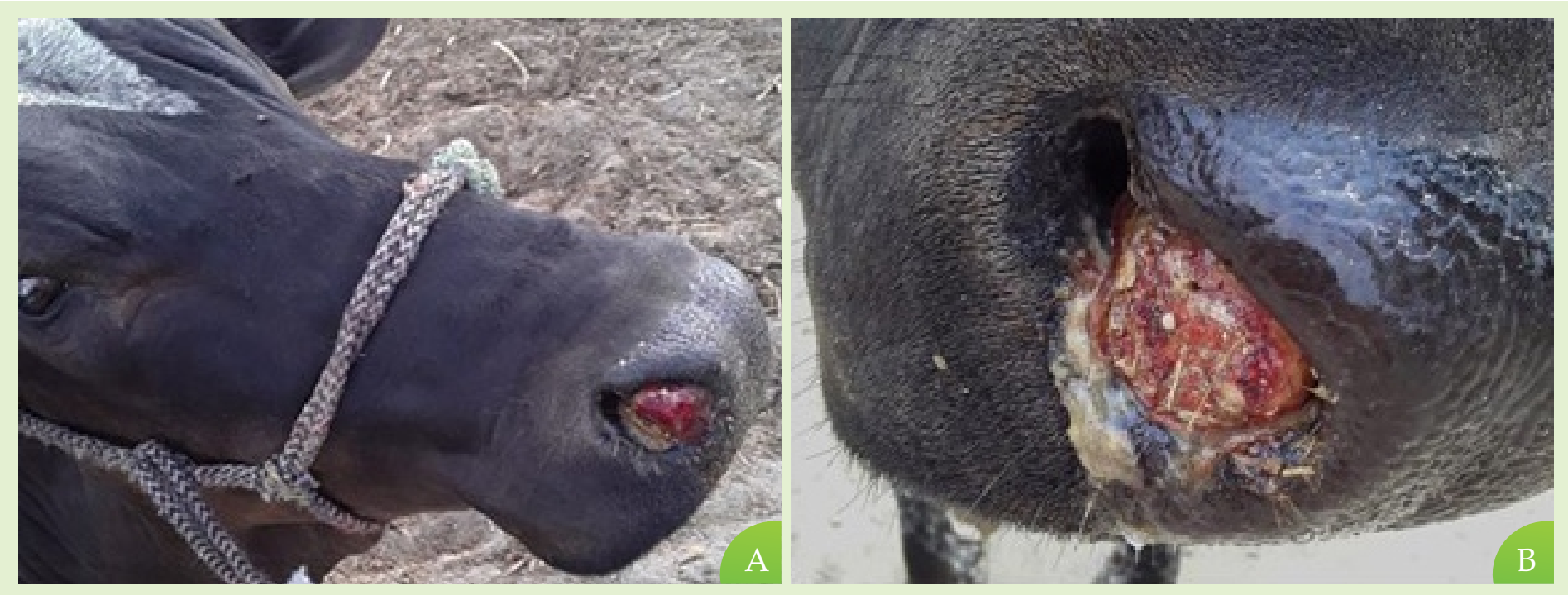

Figura 17. Granuloma nasal em bovino ocluindo parcialmente a narina direita. (A e B) Massa avermelhada de superfície irregular e (B) secreção nasal purulenta e edema na asa média da narina e vestíbulo nasal.

pequenos grânulos amarelos e duros (coloquialmente denominados grânulos de enxofre, devido a cor), presentes na maioria dos casos da doença e representam as colônias bacterianas, mas não são específicos para a actinomicose $\mathrm{e}^{112,113}$.

Em caso de osteomielite por A. bovis, devido a grande extensão e características invasivas das lesões, uma condição que deve ser incluída no diagnóstico diferencial macroscópico é o carcinoma de células escamosas (CCE) intranasal. A superfície de corte desses tumores pode apresentar pequenas estruturas amarelas, que representam as pérolas de queratina, as quais em um exame macroscópico menos detalhado poderiam ser confundidas com os grânulos de enxofre da actinomicose ${ }^{107}$.

Piogranulomas contendo centralmente bacilos filamentosos gram positivos (corados em azul pela técnica de Gram) e clavas eosinofílicas radiais (reação de Splendore-Hoeppli) são os principais achados observados na actinomicose. Reações teciduais semelhantes ocorrem com outras bactérias, particularmente A. lignieresii, porém as colônias na actinomicose são maiores e as clavas são menores e menos discretas do que na actinobacilose e, geralmente, localizadas na periferia das colônias $^{114}$.

\section{- Neoplasias da Cavidade Nasal}

Neoplasias afetando a cavidade nasal de ruminantes são pouco frequentes e geralmente cursam com lesões tumoriformes que causam obstrução, resultando em sinais clínicos semelhantes às infecções causadas por agentes infecciosos. Dentre as neoplasias da cavidade nasal destacam-se o CCE, condrossarcoma, fibrossarcoma, mixoma e tumor nasal enzoótico ${ }^{16,15,116,117}$.

Embora apresentem curso clínico variável a cronicidade é um aspecto comum entre elas ${ }^{110,15,116} \mathrm{e}$ geralmente ocasionam aumentos de volume que, dependendo da localização e extensão, podem causar obstruções, deformidades na cavidade nasal ${ }^{42,46}$, exoftalmia $^{45}$, perda de dentes e sinais nervosos ${ }^{13}$. No caso de condições obstrutivas é possível identificar ruídos respiratórios, secreção nasal, epistaxe, redução do fluxo de ar e dispneia inspiratória ${ }^{15,116}$.

Os carcinomas e sarcomas estão entre as neoplasias que apresentam dimensões maiores e são quase sempre massas pálidas e multilobuladas, compostas por tecido que varia de firme a friável. São localmente invasivas e tendem a infiltrar os seios paranasais, meninges e cérebro ${ }^{3}$. Os CCEs embora sejam frequentemente observados afetando pálpebras, orelhas, foci- 
nho, região perineal, base de chifre, região orbitária e junções mucocutâneas ocasionalmente ocorrem na cavidade nasal de ruminantes ${ }^{116,117,118}$. O acometimento da cavidade nasal geralmente ocorre como consequência de infiltração neoplásica advinda de tecidos perioculares, com destruição de conchas nasais ${ }^{119}$. Macroscopicamente os CCEs são esbranquiçados, firmes, com superfície irregular, ulcerada e às vezes aparentes na narina ${ }^{116,118}$. Ao corte podem ser observados múltiplos nódulos amarelados que correspondem a pérolas de queratina $^{117,119}$.

Histologicamente, os CCEs da cavidade nasal e seios da face, compartilham as características típicas da neoplasia vista em outras partes do corpo. As células neoplásicas apresentam núcleos grandes, centrais, muitas vezes vesiculosos, com vários nucléolos e citoplasma proeminente ${ }^{120}$, que se arranjam formando ilhas ou cordões de células epidérmicas proliferadas ou não, que se estendem através da derme, demonstrando um grau variável de diferenciação neoplásica ${ }^{117,121}$. Pérolas de queratina podem ocorrer de acordo com o grau de diferenciação das células neoplásicas e são consideradas estruturas características dessa neoplasia ${ }^{4}$.

Mixoma é uma neoplasia rara de células mesenquimais multipotenciais, distinguida por sua abundante matriz mixóide rica em polissacarídeos. São tumores solitários, irregulares, localizados no tecido subcutâneo de membros e tronco de animais domésticos adultos ou idosos, principalmente cães e gatos ${ }^{122} \mathrm{e}$ ocasionalmente ocorrem afetando a cavidade oral, nasal e região periodontal de bovinos ${ }^{1}$. No estado de Pernambuco, Nordeste do Brasil, há um registro dessa neoplasia afetando a cavidade nasal de um touro de dois anos de idade. Clinicamente o animal apresentava dispnéia, respiração estertorosa, perda de peso, aumento de volume na face lateral da narina esquerda e presença de uma massa na cavidade nasal. $\mathrm{O}$ animal foi eutanasiado e na necropsia foi observado que a massa ocupava ambas as cavidades nasais. $\mathrm{Na}$ cavidade nasal esquerda, se estendia até o seio maxilar, medindo $30 \mathrm{x}$
$17 \mathrm{~cm}$, e na cavidade nasal direita ocupava a região dorsal do seio paranasal, medindo $10 \times 5 \mathrm{~cm}$. A massa caracterizava-se por ser pobremente circunscrita, com superfície lobulada, brilhosa, branco-amarelada, cística e de consistência firme elástica ${ }^{16}$.

Um outro caso de mixoma foi observado em um caprino, macho, com aproximadamente dois anos, atendido no Hospital Veterinário Universitário da Universidade Federal da Paraíba. De acordo com o proprietário há três meses o animal apresentava secreção nasal e foi tratado com antibióticos sem resposta satisfatória. Durante o exame físico observou-se respiração ruidosa e uma massa avermelhada na porção rostral da cavidade nasal esquerda (Figura 18). Essa massa foi submetida a biopsia e o exame histopatológico revelou um mixoma. $\mathrm{O}$ animal foi abatido por opção do proprietário.

O principal diagnóstico diferencial do mixoma é o fibroma e a detecção de mucina positiva na coloração Alcian Blue pH 2,5 na matriz extracelular confirma o diagnóstico histopatológico de mixoma. A excisão cirúrgica do mixoma é recomendada ${ }^{123}$, porém quando ocorre na cavidade nasal a dificuldade de acesso limita sua remoção.

Fibrossarcoma é uma neoplasia maligna de origem mesenquimal por proliferação de fibroblastos ${ }^{124,125}$, que cursa com crescimento rápido e infiltrativo, porém metástases são incomuns ${ }^{122}$. Essa neoplasia afeta esporadicamente a cavidade nasal de bovinos ${ }^{126}$. Na Paraíba, foi diagnosticado um caso de fibrossarcoma em uma vaca adulta, sem raça definida que clinicamente apresentou dispneia mista, secreção nasal serosa bilateral, postura ortopneica (Figura 19A), aumento de volume na região do seio maxilar, discreta exoftalmia do olho direito e sialorréia. Após sete dias de internamento, o animal apresentou agravamento do quadro clínico e foi eutanasiado. Na necropsia, após corte transversal da cabeça, na altura do osso frontal, observou-se massa esbranquiçada de aparência brilhosa e consistência mole, ocupando os seios frontal, maxilar, palatino, mea- 
tos e conchas nasais da cavidade direita. Havia destruição óssea das estruturas referidas e do septo nasal com invasão da massa à cavidade nasal esquerda (Figura 19B). No exame histopatológico observou-se massa tumoral composta por células fusiformes de núcleo grande, vesicular, redondo a alongado com cromatina dispersa e citoplasma escasso e com bordas pouco delimitadas. Havia grande quantidade de fibras conectivas, coradas em azul pelo método de tricrômico de Masson e duas a três figuras mitóticas por campo de objetiva 40x. O estroma era pouco vascularizado e não delimitado ${ }^{16}$.

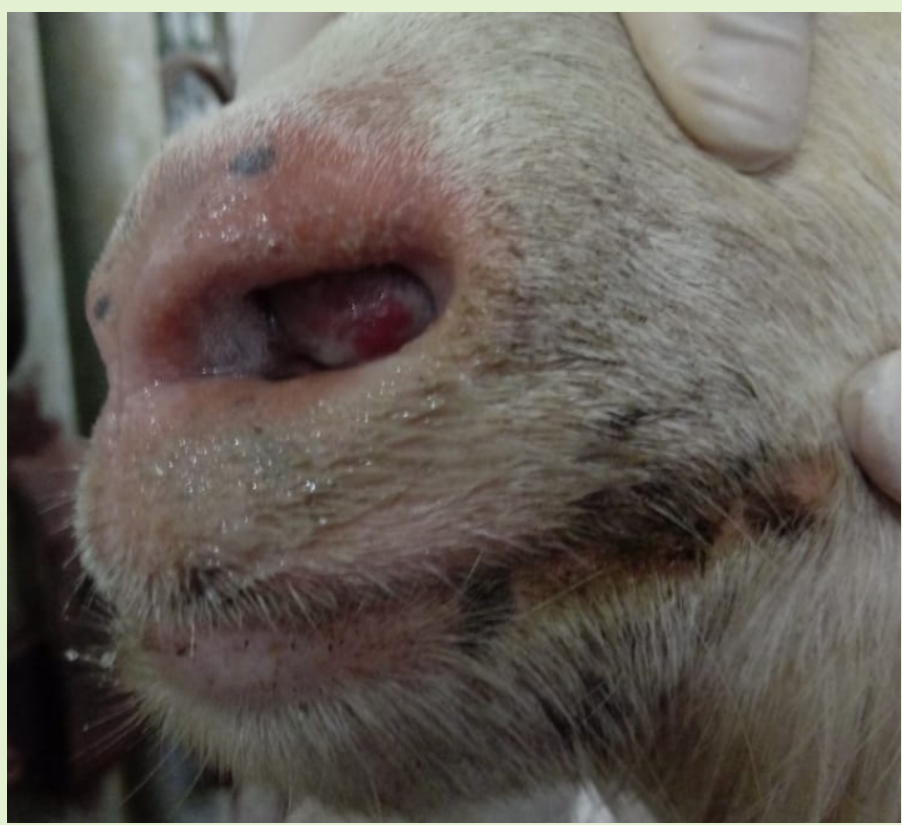

Figura 18. Mixoma nasal em caprino, apresentando massa avermelhada na porção rostral da cavidade nasal esquerda.
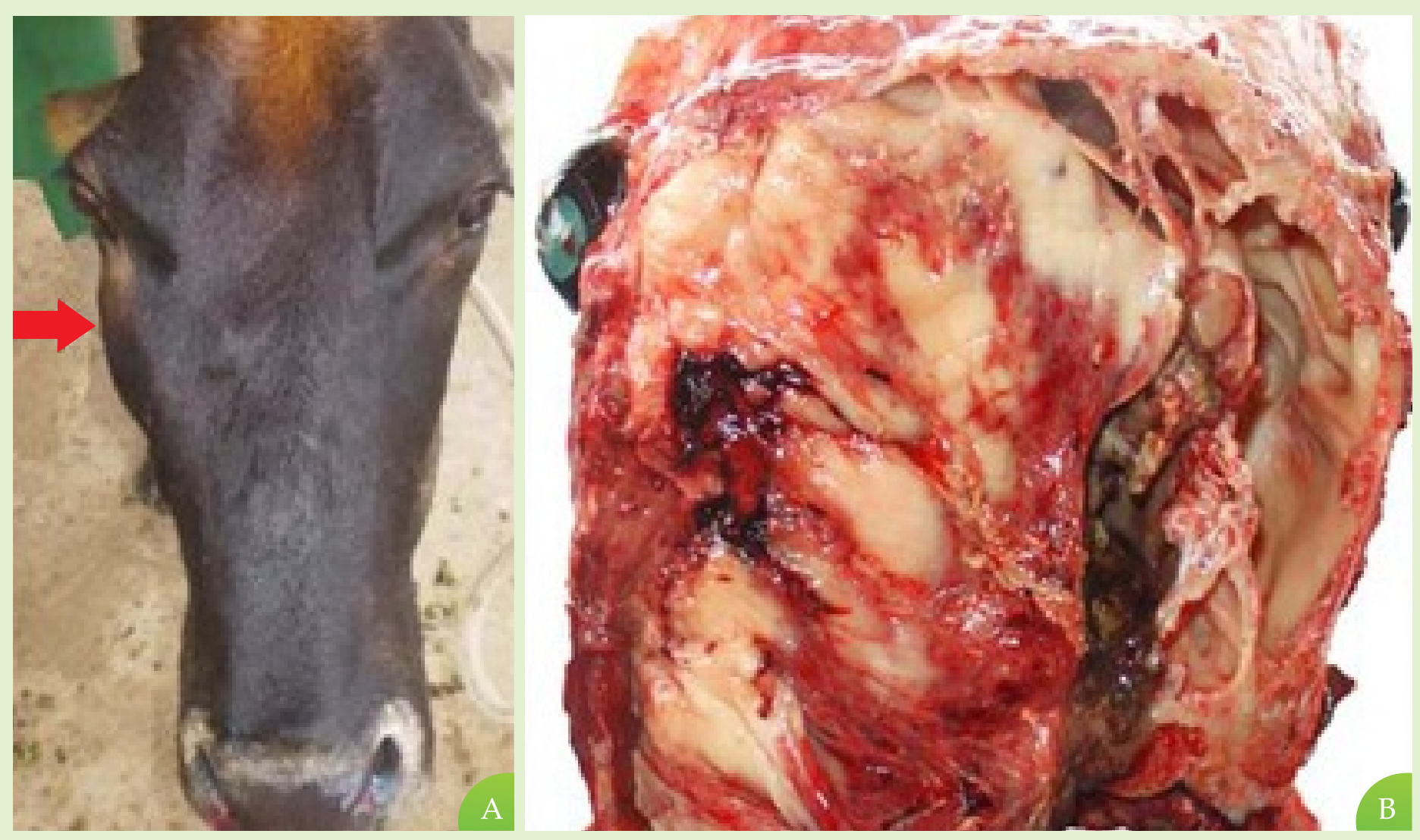

Figura 19. Fibrossarcoma nasal em um bovino. (A) Aumento de volume na região do seio maxilar (seta) e exoftalmia do olho direito e (B) corte transversal da cabeça, apresentando massa amarelo esbranquiçada, entremeadas a áreas avermelhadas, brilhosa, ocupando os seios frontais, maxilar, palatino. meatos e conchas nasais da cavidade nasal direita e invadindo a cavidade esquerda (Fotos cedidas pela Clínica Médica de Grandes Animais, Hospital Veterinário Ivon Macedo Tabosa,UFCG). 


\section{CONSIDERAÇÕES SOBRE MEDIDAS AUXILIARES AO DIAGNÓSTICO}

Para a realização do diagnóstico das enfermidades da cavidade nasal, além de uma suspeita clínica fundamentada, é importante a coleta de amostras para realização de exames complementares, que são fundamentais para identificação da etiologia do processo patológico. A qualidade da amostra disponível para análise laboratorial é essencial. Neste sentido, é importante que a coleta, o acondicionamento e envio sejam adequados, assim como a solicitação dos exames.

Independentemente do tipo de exame a ser solicitado destaca-se a necessidade que as amostras sejam acompanhadas de ficha de requisição devidamente preenchida, com informações que incluem a identificação do animal e proprietário, queixa principal, sinais clínicos, aspectos epidemiológicos, tratamentos realizados, tipo e forma de coleta das amostras. Os dados informados podem sugerir determinados agentes etiológicos, orientando a realização de exames mais adequados. Em caso de óbito, informações sobre o momento e/ou forma de eutanásia são também informações relevantes.

A necropsia mostra-se como importante ferramenta de auxílio diagnóstico, pois além da caracterização das lesões, permite a coleta de material para exames. É importante ressaltar que em quadros clínicos de doenças da cavidade nasal, independente da causa, durante a necropsia deve-se realizar a secção longitudinal da cabeça para a avaliação macroscópica e descrição das lesões quanto a localização, distribuição, coloração, formato, tamanho e consistência. $\mathrm{O}$ conhecimento da anatomia da cavidade nasal é fundamental para a descrição das lesões quanto a sua localização (Figura 20).

Para a secção é essencial o uso de uma serra. Recomenda-se que a necropsia e coleta de material para exame histopatológico seja realizada logo após a morte do animal, a fim de evitar alterações cadavéricas que dificultem o diagnóstico, bem como autólise dos tecidos. Considerando que algumas patologias estudadas além de cursarem com lesões na cavidade nasal podem comprometer outros órgãos, é importante a coleta de fragmentos de órgãos da cavidade torácica, abdominal e sistema nervoso central. Para exame histopatológico e imuno-histoquímico as dimensões das amostras devem medir aproximadamente $3 \mathrm{~cm}$ de comprimento e $1 \mathrm{~cm}$ de largura e conter uma parte de tecido normal e outra com lesão. Amostras com dimensões maiores geralmente não apresentam adequada fixação da parte interna comprometendo o diagnóstico.

A fixação das amostras deve ser realizada em solução de formol a 10\% (Figura 21) e o volume de formol utilizado deve ser dez vezes o volume dos fragmentos (10:1). Para o armazenamento das amostras recomenda-se a utilização de frascos de plástico, com boca larga capaz de permitir a retirada do material adequadamente, e com tampa de boa vedação, para evitar vazamentos e evaporação. $\mathrm{O}$ tamanho do recipiente deve suportar o volume de formol recomendado e a amostra. Os frascos de vidro devem ser evitados considerando que, em casos de coletas a campo e envio para centros de diagnóstico, pode ocorrer quebra durante o transporte. É importante realizar a troca do formol após 24 horas de fixação, sendo ideal uma nova troca após 48 horas. O tempo de fixação ideal em formol para exame imuno-histoquímico é de 48 horas, períodos prolongados de fixação podem contribuir para alterações na estrutura do antígeno, resultando em falso 




Figura 20. Secção sagital da cabeça de um ovino, demonstrando os componentes anatômicos da cavidade nasal.

negativo $^{127}$.

Em condições a campo é comum o congelamento das amostras, principalmente quando há indisponibilidade de formol, entretanto, essa prática não é recomendada quando se deseja realizar exame histopatológico e imuno-histoquímico, pois impede a obtenção de secções histológicas adequadas. Portanto, ressalta-se a necessidade que o médico veterinário inclua o formol como item básico para sua rotina clínica.

O exame histopatológico é recomendado como método auxiliar de diagnóstico para todas as doenças mencionadas nesta revisão. Em casos de suspeita de enfermidades infecciosas como pitiose, aspergilose e conidiobolomicose, bem como neoplasias, devem ser associadas a colorações histoquímicas especiais e imuno-histoquímica. As colorações histoquímicas especiais permitem a caracterização do agente etiológico e auxiliam a solicitação do exame imuno-histoquímico e identificação definitiva. A imuno-histoquímica também auxilia na identificação da origem celular em neoplasias $^{128}$.

O exame citológico tem sido indicado principalmente para diferenciar processos inflamatórios agudos ou crônicos e neoplasias benignas ou malignas, no entanto não deve substituir outros métodos como histopatologia, microbiologia e imuno-histoquímica. A coleta do material para esse exame pode ser realizada através de vários métodos, considerando principalmente o tipo de lesão. Dentre essas técnicas, destacamse a punção aspirativa por agulha fina (PAAF), o imprint direto e o indireto por meio do uso de swab.

A PAAF é indicada para lesões como massas sólidas, cistos, abscessos e granulomas. Para a realização da técnica pode ser utilizada seringa de $5 \mathrm{ou} 10 \mathrm{ml}$ com 
agulha $21 / 23 \mathrm{G}$, aspirando uma quantidade representativa de material, que em seguida é colocado em uma lâmina de vidro. Com o auxílio de outra lâmina desliza-se suavemente o material. O imprint indireto com uso do swab é uma técnica indicada principalmente para lesões com bordos elevados, trajetos fistulosos, mucosas e locais de difícil acesso ${ }^{129,130}$. O swab deve ser rotacionado sobre a lesão sempre no mesmo sentido, e em seguida deve ser rotacionado sobre a lâmina no sentido contrário ao da coleta, de forma que duas a três linhas fiquem "desenhadas" na lâmina. Salienta-se que não se deve esfregar o swab sobre a lâmina, para evitar a

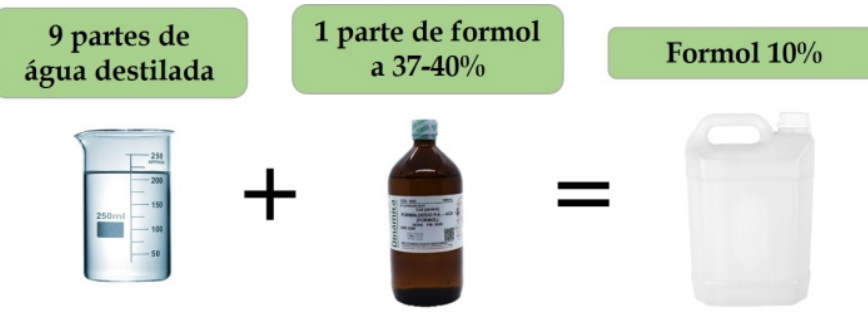

Figura 21. Representação esquemática de preparo de formol a 10\%.

degradação da amostra ${ }^{131}$.

Independentemente do método, as lâminas citológicas devem ser secas ao ar, identificadas a lápis na sua ponta fosca e enviadas ao laboratório em caixas específicas, que impeçam a adesão de uma lâmina a outra durante o transporte. Em casos de indisponibilidade das caixas, utilizam-se de dois fragmentos de papel dobrado, posicionados entre as lâminas em suas extremidades. Em seguida, as lâminas devem ser coladas por fita adesiva, evitando a queda do papel e a aderência das faces contendo a amostra (Figura 22). Caso haja disponibilidade, as lâminas devem ser fixadas em metanol P.A., não sendo possível a fixação, as lâminas devem ser encaminhadas ao laboratório em até 24 horas, para evitar a formação de artefatos ${ }^{131}$.

O método de cultivo e isolamento apresentam especificidade e sensibilidade variável, de acordo com o agente etiológico. $\mathrm{O}$ isolamento fúngico é tradicionalmente utilizado, entretanto, às vezes requer tempo e apresenta uma baixa sensibilidade e/ou especificidade.
Agentes contaminantes secundários também dificultam a realização e interpretação dessa técnica, ocasionando por vezes resultados falsos ${ }^{56,132}$. A amostra a ser coletada para exame microbiológico depende da suspeita da doença, entretanto, fragmentos de tecido lesionado da cavidade nasal ou exsudatos inflamatórios têm sido utilizados com maior frequência. Destaca-se a necessidade de coleta e armazenamento das amostras de forma asséptica, para diminuir a contaminação. Portanto, os instrumentos devem ser previamente desinfetados com álcool 70\% ou esterilizados e as amostras acondicionadas em frascos estéreis. Nos casos de coleta de amostras durante exame necroscópico recomendase que a coleta para exame microbiológico seja realizada imediatamente após a abertura da cavidade nasal. Após a coleta as amostras devem ser refrigeradas e enviadas o mais rápido possível para o laboratório em caixas isotérmicas contendo gelo reciclável, de modo a evitar a multiplicação de eventuais contaminantes. Secreções e líquidos coletados em tubos de ensaio devem estar contidos em sacos plásticos reforçados e transparentes para evitar derramamento com consequente contaminação e perda do material.

Nos últimos anos os métodos moleculares tornaram-se mais acessíveis e, devido a sua alta sensibilidade e especificidade, são indicados para identificação de patógenos que possuem crescimento in vitro extremamente lento ou fastidioso. Para as doenças da cavidade nasal essas técnicas têm sido aplicadas principalmente para o diagnóstico de doenças fúngicas e pitiose. Para análises moleculares recomenda-se a refrigeração da amostra e envio ao laboratório em até 24 horas, em caso de impossibilidade de envio deve ser congelada, para evitar autólise e degradação dos ácidos nucléicos. Cada tipo de amostra deve ser acondicionada isoladamente em frascos estéreis, identificadas, datadas e o transporte deve ser realizado em caixa isotérmica contendo gelo reciclável para melhor conservação ${ }^{133}$.

Em caso de necessidade de realização de mais de um teste diagnóstico (histopatológico, microbioló- 
Figura 22. Sugestão de método de envio de lâminas citológicas ao laboratório utilizando dois fragmentos de papel dobrado, posicionados entre as extremidades das lâminas para evitar a aderência entre as mesmas.

gico e/ou molecular) recomenda-se que as amostras para cada tipo de exame sejam coletadas de um mesmo local de origem, a fim de evitar resultados falsos.

\section{- Prognóstico e Tratamento}

A progressão da maioria das enfermidades da cavidade nasal causa grande comprometimento da região, o que leva a um prognóstico desfavorável e a não realização de tratamentos. A cavidade nasal está frequentemente obstruída por extensas lesões, não responsivas aos tratamentos medicamentosos e em locais que não permitem acesso para realização de procedimentos cirúrgicos.

O momento do diagnóstico é um fator importante para o prognóstico, pois com a evolução da doença, em algumas enfermidades, pode haver comprometimento de estruturas adjacentes como cérebro e olhos ou órgãos da cavidade torácica e abdominal, contribuindo para a irreversibilidade dos casos e altas taxas de letalidade.

Algumas tentativas de tratamento clínico podem ser realizadas, mas a taxa de sucesso é muito pequena, a exemplo do demonstrado por Carrera et al. ${ }^{30}$, onde apenas um animal respondeu positivamente a imunoterapia para tratar ovinos com pitiose nasal. A terapia com antifúngicos tem sido uma alternativa utilizada em algumas afecções. No caso de prototecose instituiu-se um protocolo com fluconazol, via oral por sessenta dias e intravenoso por quarenta dias, sem resposta eficaz ${ }^{29}$. Para a pitiose rinofacial esse mesmo antifúngico foi associado a terapia de suporte (limpeza diária da cavidade nasal, antibióticos e vitaminas), nesse caso houve recuperação do animal após 42 dias de tratamento ${ }^{16}$. A resolução dos casos de rinites infecciosas geralmente é incerta e requer longos períodos de tratamento, por isso os procedimentos ficam muitos onerosos o que inviabiliza a sua utilização em animais de produção.

$\mathrm{Na}$ oestrose o uso de anti-helmínticos é uma alternativa eficaz para o tratamento e prevenção da doença $^{96}$. Anti-inflamatórios esteroidais podem diminuir ou eliminar temporariamente os sinais clínicos produzidos pela rinite granulomatosa de origem alérgica em bovinos ${ }^{35}$.

Os procedimentos cirúrgicos podem ser utilizados para a exérese de lesões, no entanto a localização e o caráter infiltrativo de muitas lesões podem inviabilizar esses procedimentos. Em bovinos a cirurgia foi utilizada com sucesso em alguns casos de mixoma ${ }^{42}$, condrossarcoma ${ }^{115}, \mathrm{CCEs}^{116}$ e granuloma nasal por Actinomyces bovis ${ }^{110}$. 


\section{CONSIDERAÇÕES FINAIS}

As enfermidades da cavidade nasal possuem etiologia diversificada, causam graves transtornos aos animais, e os procedimentos terapêuticos utilizados são escassos e pouco efetivos. $\mathrm{O}$ retardo no diagnóstico contribui para os prognósticos desfavoráveis, dessa forma deve-se orientar os produtores que busquem auxílios no início das manifestações clínicas, evitando que os atendimentos sejam realizados em momentos em que os quadros já são irreversíveis.

É importante que o clínico veterinário domine as técnicas semiológicas necessárias ao exame do trato respiratório superior e tenha conhecimento dos aspectos epidemiológicos associados às diferentes enfermidades. Além disso, o mesmo deve realizar necropsias e utilizar, sempre que possível, as demais possibilidades diagnósticas auxiliares disponíveis, para que, após identificação da etiologia, medidas adequadas de controle e profilaxia sejam implementadas, evitando desconforto aos animais e perdas econômicas, especialmente naquelas enfermidades que podem ocorrer na forma de surtos.

\section{REFERÊNCIAS}

\section{SANTOS, R.L.S.; ALESSI, A.C.Patologia Veteri- nária.2aed. Rio de Janeiro: Roca,2017.856p.}

2.SILVA, S.M.M.S. et al. Epidemiologia e sinais clínicos da conidiobolomicose em ovinos no estado do Piauí. Pesquisa Veterinária Brasileira, v.27, n.4, p.184-190, 2007.

3. FURLAN, F.H. et al. Conidiobolomicose causada por Conidiobolus lamprauges em ovinos no estado de Santa Catarina. Pesquisa Veterinária Brasileira, v.30, n.7,p.529-532,2010.

4. RIET-CORREA, F. et al. Outbreaks of rhinofacial and rhinopharyngeal zygomycosis in sheep in Paraíba, northeastern Brazil. Pesquisa Veterinária Brasileira, v.28,n.1,p.29-35,2008.

5. LAWS, L.; SIMMON, G.C. Cripotooccosis in a sheep. Australian Veterinary Journal, v.42, n.9, p.321323, 1966.
6. SILVA, S.T.G. et al. Nasal cryptococcosis in a sheep in Brazilian Semi-Arid. Brazilian Veterinary Pathology, v.3,n.2,p.127-130,2010.

7. CARMO, P.M.S. et al. Nasal and cutaneous aspergillosis in a goat. Journal of Comparative Pathology, v.150,n.1,p.4-7,2014.

8. CARMO, P.M.S. et al. Diseases caused by Pythium insidiosum in sheep and goats: a review. Journal of Veterinary Diagnostic Investigation, v.33, n.1, p.20-24, 2020.

9. MACÊDO,J.T.S.A. et al. Cutaneous and nasal protothecosis in a goat. Veterinary Pathology, v.45, n.3, p.352-354,2008.

10. SINGH, K. et al. Granulomatous and eosinophilic rhinitis in a cow caused by Pseudallescheria boydii species complex (Anamorph Scedosporium apiospermum). Veterinary Pathology, v.44, n.6,p.917-920, 2007.

11. CONTI DÍAZ, I.A. et al. Mycotic bovine nasal granuloma. Revista do Instituto de Medicina Tropical de 
São Paulo,v.45, n.3,p.163-166, 2003.

12. BOSSCHERE, H. et al. Seasonal variation in the morphology of a bovine nasal granuloma. Veterinary Record,v.146,n.11,p.322-324,2000.

\section{LÓPEZ,A.; MARTINSON, S.A. Sistema Respi-} ratório, Mediastino e Pleuras. In: ZACHARY, J. F. (Ed). Bases da Patologia Veterinária. Rio de Janeiro: Elsevier,2018.cap. 9,p.487-488.

14. MOSES, J.S.; BALACHANDRAN, C. Rhinosporidiosis in bovines of Kanyakumari district, Tamil Nadu,India.Mycopathologia,v.100, n.1,p.23-26,1987.

15. VASCONCELOS, T.C. et al. Oestrose: uma parasitose emergente em pequenos ruminantes no Nordeste do Brasil. Pesquisa Veterinária Brasileira, v.36, n.10, p.925-929,2016.

16. PORTELA, R.A. et al. Doenças da cavidade nasal em ruminantes no Brasil. Pesquisa Veterinária Brasileira,v.30,n.10.p.844-854,2010.

17. FRASE, C.M. Sistema Respiratório. In: FRASE, C.M.Manual Merk de Veterinária:Um Manual Diagnóstico, Tratamento, Prevenção e Controle de Doenças para o Veterinário. 7aed. São Paulo: Roca, 1996. p.854-931.

18. SILVA, B.S. et al. Epidemiology of Oestrus ovis (Diptera: Oestridae) in sheep in Botucatu, State of São Paulo. Revista Brasileira de Parasitologia Veterinária, v.21, n.4,p.386-390,2012.

19. HIDALGO, A. et al. Oestrus ovis infection of grazing sheep during summer in southern Chile. Pesquisa Veterinária Brasileira, v.35, n.6, p.497-500,2015.

20. PEDROSO, P.M.O. et al. Rinitemicótica rinofa- ríngea em um ovino Texel no Rio Grande do Sul. Acta Scientiae Veterinariae, v.37, n.2,p.181-185,2009.

21. BOABAID, F.M. et al. Conidiobolomicose em ovinos no Estado de Mato Grosso. Pesquisa Veterinária Brasileira,v.28, n.1,p.77-81,2008.

22. MUSTAFA, V.S. et al. Doenças da cavidade nasal em pequenos ruminantes no Distrito Federal e no estado de Goiás. Pesquisa Veterinária Brasileira, v.35, n.7, p.627-636,2015.

23. MONTEIRO, F.D.O.; OLIVEIRA, C.R. Achados clínico-epidemiológicos sugestivos da conidiobolomicose em ovinos na região norte do Tocantins. Brazilian Journal of Development, v.6, n.9, p.71108-71113, 2020.

24. KETTERER, P.J. et al. Rhinocerebral and nasal zygomycosis caused by Conidiobolus incongruus. Australian Veterinary Journal,v.69, n.4,p. 85-87,1992.

25. SCHILD, C.O. et al. Nasal conidiobolomycosis in a sheep (Ovis aries) in Uruguay. Veterinaria, v.52, n.202, p.25-30,2016.

26. MENDONZA, L. et al. Life cycle of the human and animal oomycete pathogen Pythium insidiosum. Journal of Clinical Microbiology, v.31, n.11, p.29672973,1993.

27. PEREIRA, A.L. et al. Conidiobolomicose em caprinos. In: ENCONTRO NACIONAL DE DIAGNÓSTICO VETERINÁRIO, 7. 2014, Salvador.Anais... Salvador: 2014.

28. PAPADOPOULOS, E. et al. Comparison of infection rates of Oestrus ovis between sheep and goats kept in mixed flocks. Veterinary Parasitology, v.138, n.34,p.382-385,2006. 
29. CAMBOIM, E.K.A. et al. Protothecosis by Prototheca wickerhamii in goats. Mycoses, v.54, n.4, p.196200,2011.

30. CARRERA, M.V.et al. Pitiose em ovinos nos estados de Pernambuco e Bahia. Pesquisa Veterinária Brasileira,v.33, n.4,p.476-482,2013.

31. SILVA, B.F. et al. Parasitism by Oestrus ovis: influence of sheep breed and nematode infections. Veterinary Parasitology, v.186, n. 3-4, p.437-444,2012.

32. SCHENKEL, D.M. et al. Surto de Oestrus ovis em ovinos em Mato Grosso. Pesquisa Veterinária Brasileira, v.32,n.8,p.754-756,2012.

33. MACÊDO, A.G.C. et al. Criptococose nasal causada por Cryptococcus gattii em ovino na Bahia, Nordeste do Brasil.Acta Scientiae Veterinariae, v.48, n.561, p.18,2020 .

34. CARBONELL, P.L. Bovine nasal granuloma. Veterinary Pathology, v.16,p.60-73,1979.

35. STIGGER, D.L. et al. Granuloma nasal (rinite atópica) de bovinos. Ciência Rural, v.31, n.3, p. 461$465,2001$.

36. MENDONÇA, F.S. et al. Cobolomycosis in sheep in the state of Pernambuco. Revista Brasileira de Medicina Veterinária,v.34,n.3,p.241-246,2012.

37. CARDONA,J.A. et al. Descripción clínica e histopatológica de la rinitis micótica granulomatosa en ovinos de Córdoba, Colombia. Revista da Faculdade de Medicina Veterinária e de Zootecnia da Universidade Nacional da Colômbia, v.59, n.3, p.51-158,2012.

38. PEIXOTO, T.C. et al. Surtos de conidiobolomicose ovina por Conidiobolus lamprauges no estado da
Bahia, Nordeste do Brasil. Brazilian Journal of Veterinary Medicine, v.39, n.4, p.252-263,2017.

39. AGUIAR, G.M.N. et al. Aspectos epidemiológicos da conidiobolomicose em ovinos na região semiárida do Nordeste do Brasil. Ciência Rural, v.44, n.12, p.2210-2216, 2014.

40. GOLONI, A.V. et al. Pitiose rinofacial em ovino: relato de caso. Arquivos de Pesquisa Animal,v.1, n.1,p.16,2014.

41. BERNARDO, F.D. et al. Pythiosis in sheep from Paraná, southern Brazil. Pesquisa Veterinária Brasileira, v.35, n.6,p.513-517,2015.

42. SINGH, C.K. et al. Myxoma in the nasal cavity of a Holstein cross bred cow. Israel Journal of Veterinary Medicine,v.71,n.4,p.45-48,2016.

43. SANTURIO, J.M. et al. Granulomatous rhinitis associated with Pythium insidiosum infection in sheep. Veterinary Record,v.164,n.9, p.276-277,2008.

44. WEIBLEN, C. et al. Epidemiological, clinical and diagnostic aspects of sheep conidiobolomycosis in Brazil. Ciência Rural,v.46, n.5,p.839-846, 2016.

45. BRAUN, U. et al. T-cell lymphoma in the nasal cavity of a Brown Swiss heifer. Acta Scientiae Veterinariae,v.57,n.8,p.1-5, 2015.

46. SANTOS, A. et al. Osteossarcoma osteoblástico nasal em um bovino Wagyu. Acta Scientiae Veterinariae, v.44,n.1,p.147-151,2016.

47. CÂMARA, A.C.L. et al. Rhinocerebral and rhinopharyngeal conidiobolomycosis in sheep. Ciência Rural,v.41,n.5,p.862-868,2011. 
48. SMITH, M.C.; SHERMAN, D.M. Respiratory System. In: SMITH, M.C.; SHERMAN, D.M. Goat Medicine. 2aed. Iowa: Willey-Blackwell, 2009. p.339376.

49. FEITOSA, F.L.A Semiologia do Sistema Respiratório. In: FEITOSA, F. L. Semiologia Veterinária. 4aed. Rio de Janeiro: Roca.2020.p.257.

50. FEITOSA, F.L. Exame Físico Geral ou de Rotina. In: FEITOSA, F.L. Semiologia Veterinária. 4ªed. Rio de Janeiro: Roca.2020.p47.

51. STOBER, M. Aparelho Respiratório. In: ROSENBERGER, G. Exame Clínico dos Bovinos. 3aed. Rio de Janeiro: Guanabara Koogan, 1993. p.139165.

52. HARR, G.T. Diseases of the nose, nasal plane, nasal cavity and frontal sinus. In: WORLD SMALL ANIMAL VETERINARY ASSOCIATION WORLD CONGRESS PROCEEDINGS.36, 2006. Praga.Anais...Praga:2006.

53. WEIBLEN, C. et al. Epidemiological, clinical and diagnostic aspects of sheep conidiobolomycosis in Brazil. Ciência Rural,v.46, n.5,p.839-846, 2016.

54. CARRIGAN, M.J. et al. Ovine nasal zygomycosis caused by Conidiobolus incongruus. Australian Veterinary Journal,v.69, n.10, p.237-240,1992.

55. MORRIS, $M$. et al. Rhinocerebral zygomycosis in a sheep. Canadian Veterinary Journal, v. 42, n.3, p.227$228,2001$.

56. RIBES, J.A. et al. Zygomycetes in human disease. Clinical Microbiology Reviews, v.13, n.2, p.236-301, 2000.
57. HUMBER, R.A. et al. Equine zygomycosis caused by Conidiobolus lamprauges. Journal of Clinical Microbiology,v.27, n.3, p.573-576, 1989.

58. VILELA, R. et al. Morphologic and phylogenetic characterization of Conidiobolus lamprauges recovered from infected sheep. Journal of Clinical Microbiology, v.48, n.2, p.427-432, 2010.

59. UBIALI, D.G. et al. Pathology of nasal infection caused by Conidiobolus lamprauges and Pythium insidiosum in sheep. Journal of Comparative Pathology, v.49, n.2-3, p.137-145, 2013.

60 SILVA, S.T.G. et al. Nasal cryptococcosis in a sheep in Brazilian Semi-Arid. Brazilian Veterinary Pathology, v.3,n.2,p.127-130,2010.

61. DE CECCO, B.S. et al. Detection of Enzootic Nasal Tumor Virus (ENTV) in a sheep flock in southern Brazil. Tropical Animal Health and Production, v.51,n.7,p.2095-2098,2019.

62. DE PAULA, A.J. et al. Molecular characterization of ovine zigomicosis in Central Western Brazil.Journal of Veterinary Diagnostic Investigation, v.22, n.2, p.274$277,2010$.

63. SILVEIRA,M.M. et al. Development and application of polymerase chain reaction test for detection of Conidiobolus lamprauges. Pesquisa Veterinária Brasileira, v.33,p.1448-1452,2013.

64. TABOSA, I.M. et al. Outbreaks of pythiosis in two flocks of sheep in Northeastern Brazil. Veterinary Pathology,v.41,n.4,p.412-415,2004.

65. PESSOA, C.R.M. et al. Pythiosis of the digestive tract in sheep. Journal of Veterinary Diagnostic Investigation,v.24,n.6,p.1133-1136, 2012. 
66. MARTINS, T.B. et al. A comparative study of the histopathology and immunohistochemistry of pythiosis in horses, dogs and cattle. Journal of Comparative Pathology,v.146,n.2-3, p.122-131,2011.

67. GATTA, L.B. et al. Application of alternative fixatives to formalin formalin in diagnostic pathology. European Journal of Histochemistry, v.56, n.2, p.63-70, 2012.

68. MAIA, L.A. et al. Pythiosis in cattle in Northeastern Brazil. Pesquisa Veterinária Brasileira, v.40, n.5, p.340-345,2020.

69. GALIZA, G.J.N. et al. Ocorrência de micoses e pitiose em animais domésticos: 230 casos. Pesquisa Veterinária Brasileira, v.34,n.3, p.224-232,2014.

70. GABRIEL, A.L. et al. Surto de pitiose cutânea em bovinos. Pesquisa Veterinária Brasileira, v.28, n.12, p.583-587,2008.

71. MAGALHÃES, G.M. et al. Cerebral cryptococcomas in a cow. Journal of Comparative Pathology,v.147,n.2-3,p.106-110,2012.

72. BIANCHI, R.M. et al. Pneumonia by Cryptococcus neoformans in a goat in the Southern region of Brazil. Ciência Rural,v.48.n.10,p.1-5,2018.

73. RIET-CORREA, F. et al. Bovine cryptococcal meningoencephalitis. Journal of Veterinary Diagnostic Investigation, v.23,n.5,p.1056-1060,2011.

74. ZHOU, Y. et al. Survey of mycotic mastitis in dairy cows from Heilongjiang Province, China. Tropical Animal Health and Production, v.45, n.8, p.1709-1714, 2013.

75. CHAPMAN, H.M. et al. Cryptococcus neoformans infection in goats. Australian Veterinary Journal, v.67, n.7,p.263-265, 1990.

76. PAPPALARDO,M.C.S.M.; MELHEM, M.S.C. Cryptococcosis: a review of the brazilian experience for the disease. Revista do Instituto de Medicina Tropical de São Paulo,v.45, n.6,p.299-305, 2003.

77. CHATURVEDI, V.; CHATURVEDI, S. Cryptococcus gattii: a resurgent fungal pathogen. Trends in Microbiology,v.19, n.11,p.565-571,2011.

78. PAULA, D.A.J. et al. Occurrence and molecular characterization of cryptococcosis in dogs and cats in Mato Grosso, Brazil. Pesquisa Veterinária Brasileira, v.34,n.2,p.167-172, 2014.

79. BOSCO, S. M.G. et al. Doenças Infecciosas em Animais de Produção e Companhia. 1ªed. Rio de Janeiro: Roca,2016.cap 84, p.884-885.

80. CASTELLÁ, G. et al. Criptococosis y animales de Compañía. Revista Iberoamericana de Micología, v.25, n.1,p.19-24,2008.

81. MAIA, L.A. Doenças fúngicas em bovinos e asinino. 2016.74f. Tese (Doutorado em Medicina Veterinária) - Universidade Federal de Campina Grande, Centro de Saúde e Tecnologia Rural,Patos, Paraíba.

82. RIZZO, H. et al. Aspergillus fumigatus em pulmão de ovino no Brasil - relato de caso. Revista Brasileira de Medicina Veterinária, v.38, n.4, p.413-419,2016.

83. VESTWEBER, G.J.; LEIPOLD H.W. Pulmonary and mammary aspergillosis in a dairy cow. Canadian VeterinaryJournal,v.35,n,12,p.780,1995.

84. MANDAL, P.C.; GUPTA, P.P. Sequential pathological studies in goats infected intratracheally with 
Aspergillus fumigatus. Mycopathologia, v.121, n.2, p.7781,1993.

85. NEITZKE, J.P.; SCHIEFER, B. Incidence of mycotic gastritis in calves up to 30 days of age. Canadian Veterinary Journal,v.15, n.5,p.139-144,1974.

86.JENSEN, H.E. et al. Mycosis in the stomach compartments of cattle. Acta Veterinaria Scandinavica, v.30, n.4,p.409-423, 1989.

87. SEYEDMOJTABA, S. et al. Aspergillus and aspergilosis in a wild and domestic animals: a global health concern with parallels to human disease. MedicalMycology,v.53, n.8, p.765-797,2015.

88. TELL, L. A. Aspergillosis in mammals and birds: impact on veterinary medicine. Journal of Medical Mycology,v.43,p.71-73,2005.

89. BENNETT, J.W. An Overview of the Genus Aspergillus. In: MACHIDA, M.; GOMI, K. Aspergillus Molecular Biology and Genomics. Norfolk: Caister Academic Press,2010.p.1-17.

90. PERRY, J.J. et al. Pathology in practice. Disseminated aspergillosis. Journal of the American Veterinary MedicalAssociation, v.236, n.2, p.173-175,2010.

91. FUKUZAWA, M. et al. Improved detection of medically important fungi by immunoperoxidase staining with polyclonal antibodies. Virchows Arch, v.427,n.4,p.407-414,1995.

92. CARNEIRO, F.P. et al. Prototecose cutânea: relato de caso. Revista da Sociedade Brasileira de Medicina Tropical,v.40, n.4,p.466-468,2007.

93. BORGES, I.L. et al. Rinite micótica em caprino: relato de caso. Pesquisa Veterinária Brasileira, v.36, n.2, p.189-191,2016.

94. THIELE, D.; BERGMANN, A. Protothecosis in human medicine. International Journal of Hygiene and Environmental Health,v.204, n.5-6, p.297-302,2002.

95.YLMA,J.M.; DORCHIES,P.H. Epidemiology of Oestrus ovis in southwest France. Veterinary Parasito$\log y$, v.40, n.3, p.315-323, 1991.

96. GARCIA, M.J. et al. Oestrosis: parasitism by Oestrus ovis. Small Ruminant Research, v.181, p.91-98, 2019.

97. CARACAPPA, S. et al. Epidemiology of ovine oestrosis (Oestrus ovis Linné, 1761, Diptera: Oestridae) in Sicily. Veterinary Parasitology, v.92, n.3, p.233-237, 2000.

98. RAMOS, C.I. et al. Epidemiologia de Oestrus ovis (Diptera: Oestridae) em ovinos no Planalto Catarinense. Ciência Rural,v.36, n.1,p.173-178,2006.

99. ANGULO-VALADEZ, C.E. et al. Nasal bots... a fascinating world! Veterinary Parasitology, v.174, n.1-2, p.19-25,2010.

100. ABO-SHEHADA, M.N. et al. Age and seasonal variations in the prevalence of Oestrus ovis larvae among sheep in northern Jordan. Preventive Veterinary Medicine,v.47,n.3,p.205-212,2000.

101. PEMBERTON, D.H. et al. Bovine nasal granuloma (atopic rhinitis) in Victoria. Experimental reproduction by the production of immediate type hypersensitivity in the nasal mucosa. Australian Veterinary Journal,v.53, n.5,p.201-207,1977.

102. KRAHWINKEL, D.J. et al. Familial allergic rhinitis in cattle. Journal of the American Veterinary Medical 
Association, v.192, n.11,p.1593-1596,1988.

103. PEMBERTON, D.H.; WHITE, W.E. Bovine nasal granuloma in Victoria. 2. Histopathology of nasal, ocular and orallesions. Australian Veterinary Journal, v.50, n.3, p.89-97, 1974.

104. GONÇALVES, M.A. et al. Granuloma nasal associado a infecção por Coccidioides immitis em um bovino no Rio Grande do Sul. In: SALÃO INTERNACIONAL DE ENSINO, PESQUISA E EXTENSÃO, 3.2013,Uruguaiana.Anais...Uruguaiana:n.2,2013.

105. AINSWORTH, G.C.; AUSTWICK, P.K. Fungal Diseases of Animals. Review series $n^{\circ} 6$ of the commonwealtii bureau of animal health. 1959. p.1143.

106. CASWETT, J.L.; WILLIAMS, K.J. Infectious Diseases of the Respiratory System. In: MAXIE, M. G. Jubb, Kennedy \& Palmer Pathology of Domestic Animals. 5a ed. London: Saunders, 2007. v.2, p.579648.

107.WILSON,D.W.; DUNGWOTH, D.L.Tumors of the Respiratory Tract. In: MEUTEN, D.J. (Ed.). Tumors in Domestic Animal. Ames: Iowa State Press, 2005.p.365-399.

108. THOMPSON, K. Inflammatory Diseases of Bones. In: MAXIE, M.D. Jubb, Kennedy \& Palmer

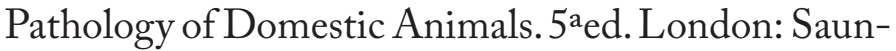
ders, 2007.v.1,p.92-105.

109. PEEK, S.F. et al. Rebhun's Respiratory Disease. In: DIVERS, T.J.; PEEK, S.F. Disease of Dairy Cattle. 3aed.Missouri: Elsevier,2018,p.94-167.

110. CHANDRATRE, G.A.et al. Nasal granuloma in buffalo: an unusual case of Actinomycosis. International Journal of Current Microbiology and Applied Sciences, v.6,n.4,p.762-765,2017.

111.TESSELE, B. et al.Actinomicose atípica em bovinos. Pesquisa Veterinária Brasileira, v.34,n.7,p.663-666, 2014.

112. BREWER, J.S. Discussion and case history: actinomycosis. Iowa State College Veterinarian, v.18, n.3, p.145-208, 1956.

113. MILLER, M.; HADDAD, A.J. Cervicofacial actinomycosis. Oral Surgery, Oral Medicine, Oral Pathology and Oral Radiology, v.85, n.5, p.496-508, 1998.

114. TILL, D.H.; PALMER, F.P.A. A review of actinobacillosis with a study of the causal organism. Veterinary Record,v.72, n.27, p.527-543, 1960.

115. BEYTUT, E. et al. Nasal chondrosarcoma in a Simmental cow. Canadian Veterinary Journal, v.47, n.4, p.349-351,2006.

116. BANIADAM, A. et al. Nasal squamous cell carcinoma in a cow. Turkish Journal of Veterinary and Animal Sciences, v.34,n.3,p.303-305,2010.

117. RAMOS, T.A. et al. Carcinoma de células escamosas em bovinos, ovinos e eqüinos: estudo de 50 casos no Rio Grande do Sul. Brazilian Journal of Veterinary Research and Animal Science, v.44, supl., p.5-13,2007.

118. CARVALHO, F.K.L. et al. Estudo retrospectivo das neoplasias em ruminantes e equídeos no semiárido do Nordeste Brasileiro. Pesquisa Veterinária Brasileira, v.34,n.3,p.211-216, 2014.

119. MORAIS, R.M. et al. Carcinoma de células esca- 
mosas ocular com invasão intracraniana e nasal em bovinos. In: ENCONTRO NACIONAL DE DIAGNÓSTICO VETERINÁRIO/II ENCONTRO INTERNACIONAL DE SANIDADE DE ANIMAIS DE PRODUÇÃO, 8. 2014, Cuiabá.Anais...Cuiabá: 2014.

120. MEUTEN, D.J. Tumors in Domestic Animals. 4aed.Ames: Iowa State Press, 2002.p.45-118.

121. FERNANDES, C.G. Neoplasias em Ruminantes e Equinos. In: RIET-CORREA, F. et al. Doenças de Ruminantes e Eqüinos. 3 ed. Santa Maria: Pallotti, 2007.p.650-656.

122. GOLDSCHMIDT, M.H.; HENDRICK, M.J. Tumors of the Skin and Soft Tissues. In: MEUTEN,J. D. Tumors in Domestic Animals. 4a ed. Ames: Iowa State Press, 2002.p.45-117.

123. GINN, P.E. et al. Skin and appendages, p.553781. In: MAXIE, M.G.Jubb, Kennedy \& Palmer Pathology of Domestic Animals. $5^{\mathrm{a} e d}$. London: Saunders, 2007.v.1,p.553-781.

124. VALLEJOTIMARAN, D.A. et al. Fibrosarcoma cutáneo en un bovino: reporte de caso. CES Medicina Veterinaria y Zootecnia, v.10, n.2, p.214-223, 2015.

125. FURUKAMA, C.A. et al. Fibrossarcoma Oral em um Bovino - Relato de Caso. In: PEREIRA, A. M. et al. A Pesquisa nos Diferentes Campos da Medicina Veterinária. 2a ed. Ponta Grossa: Atena Editora, 2020. p.172-180.

126. BRITT, L. et al. Facial fibrosarcoma in two cows. Veterinary Radiology E Ultrasound, v.39, n.1, p.18-21, 1998.

127. RAMOS-VARA, J.A.; BEISSENHERZ, M.E.
Optimization of immunohistochemical methods using two different antigen retrieval methods on formalin-fixed paraffin-embedded tissues: experience with 63 markers. Journal of Veterinary Diagnostic Investigation, v.12,n.4,p.307-311,2000.

128. EYZAGUIRRE, E.; HAQUE, A.K. Application of immunohistochemistry to infections. Archives of Pathology E Laboratory Medicine, v.132, n.3, p.424431,2008.

129. FERREIRA, J.S. Aplicação da citologia no diagnóstico de doenças infecciosas nos animais domésticos: revisão de literatura. Ciência Animal Brasileira, v.25, n.1,p.18-24,2015.

130.PELETEIRO,M.C. et al.Atlas de Citologia Veterinária.(1ªed).Lisboa: Lidel,2011.308p.

131. MEYER, D.J. The Acquisition and Management of Cytology Specimens. In: RASKIN, R.E.; MEYER, D.J. Canine and Feline Citology: A Color Atlas and Interpretation Guide. 3ªed. Amsterdã: Elsevier, 2016. p.1-15.

132. GROOTERS, A.M. et al. Evaluation of microbial culture techniques for the isolation of Pythium insidiosum from equine tissues. Journal of Veterinary Diagnostic Investigation, v.14, n.4, p.288-294, 2002.

133. MELO, M.R. et al. Coleta, transporte e armazenamento de amostras para diagnóstico molecular. Jornal Brasileiro de Patologia e Medicina Laboratorial, v.46, n.5,p.375-381,2010. 